\title{
33. CALCAREOUS NANNOPLANKTON FROM THE WESTERN NORTH ATLANTIC DSDP LEG 44
}

\author{
Ronald R. Schmidt, Geologisch Instituut der Rijksuniversiteit te Utrecht, Utrecht, The Netherlands
}

\section{INTRODUCTION}

Calcareous nannoplankton were recovered from all sites and most of the intervals cored during DSDP Leg 44. The locations of the sites are shown in Figure 1. In the samples studied, calcareous nannoplankton assemblages ranged from Upper Jurassic to Quaternary. The zonal and age assignments of the cores are summarized in Table 1. The radiometric ages for the Cenozoic nannoplankton zones follow those of Berggren (1972), with some modifications for the Neogene as suggested by Ryan et al. (1974). The radiometric ages for the Jurassic and Cretaceous zones are from van Hinte (1976a, b). These time scales form the basis for calibration of sedimentation rates when only calcareous nannofossils are found.

Several core sequences are of particular interest for calcareous nannoplankton studies. An almost continuously cored sequence of the uppermost JurassicLower Cretaceous was recovered from the BlakeBahama Basin (Hole 391C, Cores 9-54). Assemblages of Tithonian or upper Kimmeridgian to lower Albian are recognized in succession.

On the Blake Nose (Holes 390, 390A, 392A), Barremian to Albian assemblages are separated by a hiatus from upper Campanian to Maestrichtian assemblages. A nearly complete upper Campanian to Maestrichtian sequence was recovered in Hole 390A (Cores 11-14) and coverage continues in Hole 390A (Cores 1-11) in which lower Paleocene to middle Eocene assemblages are present in nannofossil ooze.

In the Blake-Bahama Basin (Holes 391A, Cores 3-20; 391C, Cores 2-3), nannofossil assemblages of lowerupper Miocene were recovered from gravity-flow deposits in association with reworked Cretaceous and Eocene-Oligocene species. Hemipelagic clay from the lower continental rise hills (Hole 388A, Cores 4-11) contains middle-upper Miocene age assemblages.

Quaternary assemblages were cored discontinuously in several holes of Leg 44.

\section{CALCAREOUS NANNOPLANKTON ZONATION}

In this paper I have followed the standard Tertiary and Quaternary zonation of Martini (1971) with some modifications. The biostratigraphic study of Gartner (1971) on JOIDES cores from the Blake Plateau forms an important additional source for comparison of the Paleocene-Eocene interval. A zonation compiled by Martini (1976) is most applicable for the Upper Cretaceous (upper Campanian-Maestrichtian). The zonations of Thierstein $(1971,1973)$ for the Lower Cretaceous and Barnard and Hay (1974) for the Jurassic are combined for the uppermost JurassicLower Cretaceous interval.
The remarks below are confined to those zones used in a different sense from the original definitions or where some clarification is necessary.

\section{Quaternary}

Combined Gephyrocapsa oceanica/Emiliania huxleyi zonal interval (NN 20/21)

Remarks: As Emiliania huxleyi is difficult to recognize in the light microscope, the two uppermost nannoplankton zones are tabulated as one unit. The base of this interval is the last occurrence of Pseudoemiliania lacunosa and the interval is assigned to the upper Quaternary. In some cores, specimens of Pseudoemiliania lacunosa may have been displaced by Pliocene reworking.

\section{Middle Eocene}

\section{Sphenolithus furcatolithoides Zone (NP 16)}

Definition: Interval from the last occurrence of Nannotetrina alata to the last occurrence of Sphenolithus furcatolithoides.

Remarks: In the standard zonation (Martini, 1971), the boundary between the Nannotetrina alata Zone (NP 15 ) and the Discoaster tani nodifer Zone (NP 16) is defined by the last occurrence of Rhabdosphaera gladius. This taxa was not encountered in the uppermost cores of Site 390 and recognition of the precise boundary between the two standard zones was not possible. The Sphenolithus furcatolithoides Zone corresponds to the Reticulofenestra umbilicaSphenolithus furcatolithoides Zone of Gartner (1971). In the Black Plateau cores, the last occurrence of Sphenolithus furcatolithoides is near the top of this zone (Gartner, 1971, p. 106). The first occurrence of Pemma papillatum forms the upper boundary of Gartner's Reticulofenestra umbilica-Sphenolithus furcatolithoides Zone. Pentalithids with a crenulated margin presumed to be transitional to Pemma papillatum are present in Core 390-1. Sphenolithus furcatolithoides with two extremely long, bifurcating apical spines, Chiasmolithus titus, and Discoaster tani nodifer are characteristic of this interval.

\section{Nannotetrina alata Zone (NP 15)}

Definition: Interval from the first occurrence of Nannotetrina alata (or Chiasmolithus gigas) to the last occurrence of Nannotetrina alata.

Remarks: In the standard zonation (Martini, 1971), the total range of the index species includes the Nannotetrina alata Zone (NN 15) and the lowermost part of the Discoaster tani nodifer Zone (NN 16). By comparison with the Blake Plateau zonation of Gartner 


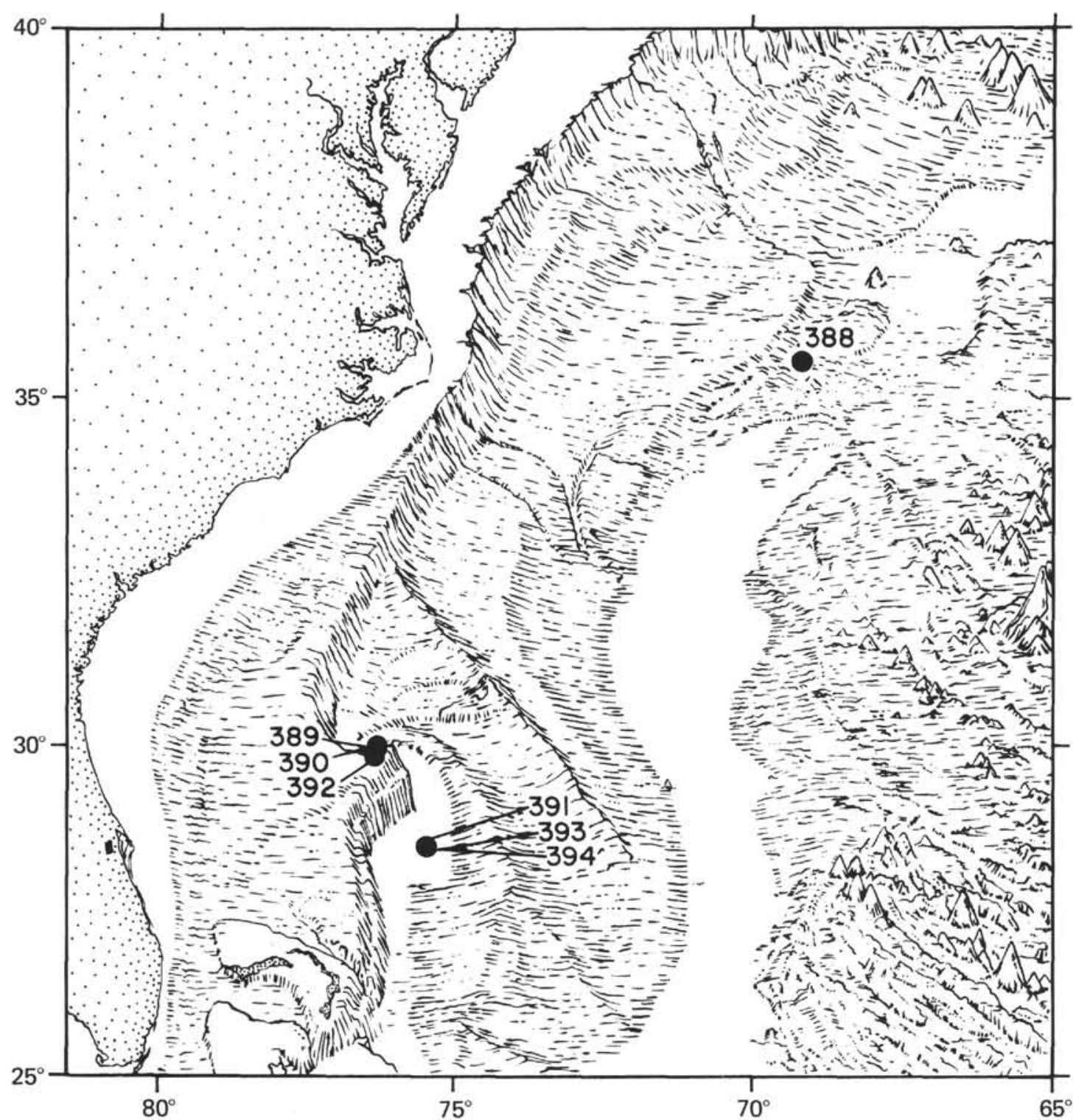

Figure 1. Location of the sites drilled during Legs 44 and $44 A$ in the western North Atlantic.

(1971), the Nannotetrina alata Zone (emended) correlates to the interval of the Chiphragmalithus quadratus Zone and the Discoaster tani s.l.-Sphenolithus radians Zone. The first occurrence of Chiasmolithus gigas is included in the zonal definition to accommodate a sample interval in Hole 390A in which the nominate index species for both the Nannotetrina alata Zone (NN 15) and the underlying Discoaster sublodoensis Zone (NN 14) are locally absent.

\section{Lower Paleocene}

\section{Biscutum dimorphosum Zone ( \pm NP 3)}

Definition: Interval from the first occurrence of Biscutum dimorphosum to the first occurrence of Ellipsolithus macellus.

Remarks: Biscutum dimorphosum is used as a substitute index marker corresponding approximately to the Chiasmolithus danicus Zone (NP 3) of Martini (1971). During the early Paleocene there was a gradual turning of the central crossbars that gave rise to the first Chiasmolithus species: either Chiasmolithus danicus or C. consuetus. Following the distinctions for the two species as given by Gartner (1970), the earliest Chiasmolithus specimens are referred to $C$. consuetus. The presence of Chiasmolithus danicus, with faintly split crossbars, could not be confirmed.

Biscutum dimorphosum, often as complete coccospheres, occurs abundantly in the same sample interval in which the first Chiasmolithus species are found. This characteristic species is an unequivocal zonal marker for samples in Cores 390A-12 and -13 .

\section{Cruciplacolithus tenuis Zone ( \pm NP 2)}

Definition: Interval from the first occurrence of Cruciplacolithus s.s. to the first occurrence of Biscutum dimorphosum.

Remarks: Cruciplacolithus tenuis is characterized by crossbars that are aligned with the long and short axes of the ellipse. Smaller specimens with a similar 
TABLE 1

Calcareous Nannoplankton Biostratigraphy and Age Assignments of the Holes Drilled During Leg 44

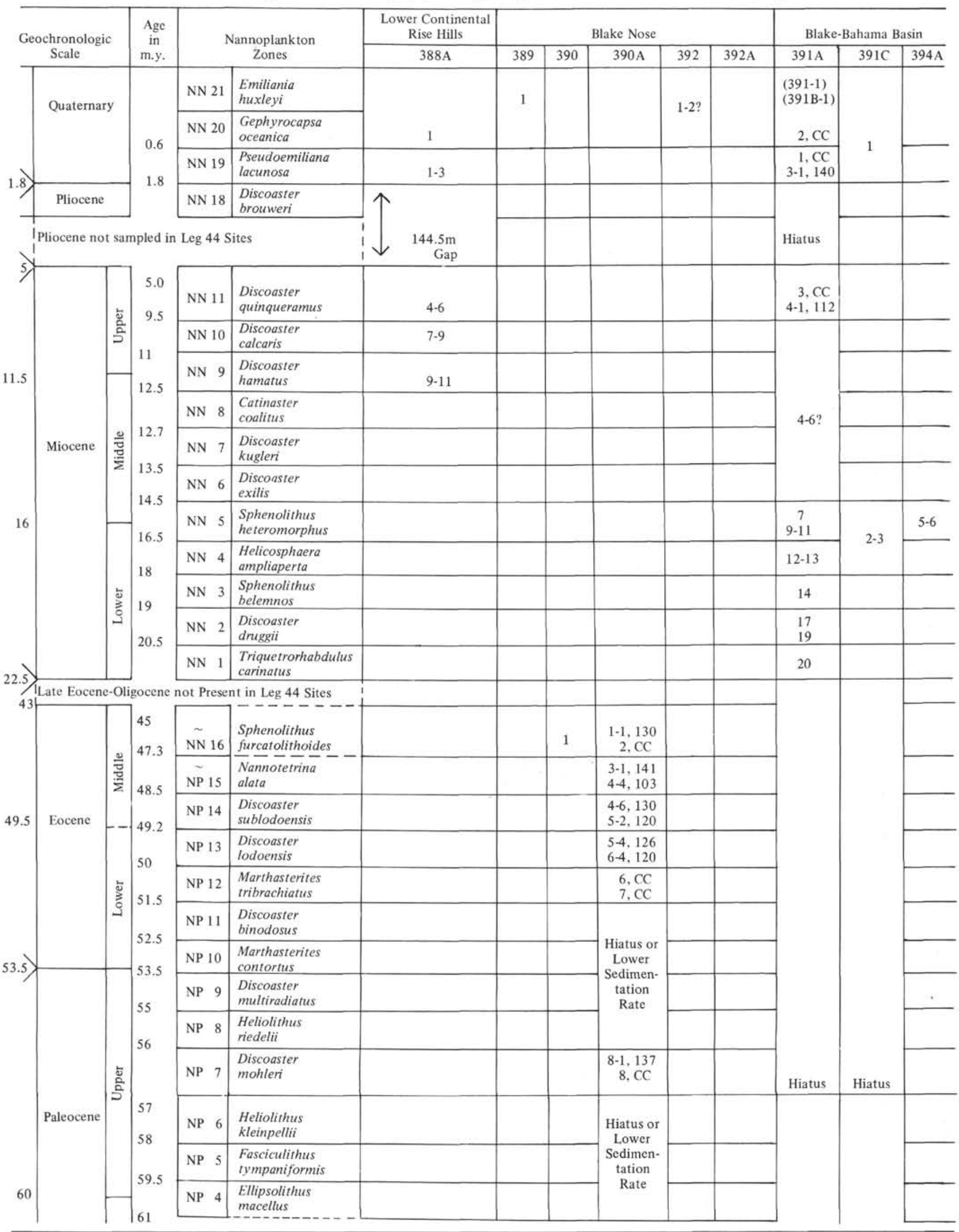


TABLE 1 - Continued

\begin{tabular}{|c|c|c|c|c|c|c|c|c|c|c|c|c|c|c|}
\hline \multirow{2}{*}{\multicolumn{3}{|c|}{$\begin{array}{l}\text { Geochronologic } \\
\text { Scale }\end{array}$}} & \multirow{3}{*}{$\begin{array}{c}\begin{array}{c}\text { Age } \\
\text { in } \\
\text { m.y. }\end{array} \\
63.5\end{array}$} & \multirow{2}{*}{\multicolumn{2}{|c|}{$\begin{array}{l}\text { Nannoplankton } \\
\text { Zones }\end{array}$}} & \multirow{3}{*}{$\begin{array}{c}\text { Lower Continental } \\
\text { Rise Hills }\end{array}$} & \multicolumn{5}{|c|}{ Blake Nose } & \multicolumn{3}{|c|}{ Blake-Bahama Basin } \\
\hline & & & & & & & 389 & 390 & $390 \mathrm{~A}$ & 392 & $392 \mathrm{~A}$ & $391 \mathrm{~A}$ & $391 \mathrm{C}$ & $394 \mathrm{~A}$ \\
\hline & \multirow{3}{*}{ Paleocene } & \multirow{3}{*}{ e } & & \begin{tabular}{ll|}
$\tilde{N P}$ & 3 \\
\end{tabular} & $\begin{array}{l}\text { Biscutum } \\
\text { dimorphosum }\end{array}$ & & & & $\begin{array}{r}9-1,102 \\
11-1,137\end{array}$ & & & & & \\
\hline & & & \multirow{2}{*}{$\begin{array}{l}64 \\
65\end{array}$} & NP 2 & $\begin{array}{l}\text { Cruciplacolithus } \\
\text { tenuis }\end{array}$ & & & & $\begin{array}{l}11-2,93 \\
11-5,35\end{array}$ & & & & & \\
\hline & & & & $\begin{array}{ll}\text { NP } & 1\end{array}$ & $\begin{array}{l}\text { Markalius } \\
\text { inversus }\end{array}$ & & & & $\begin{array}{l}11-5,50 \\
11-5,145\end{array}$ & & & & & \\
\hline & \multirow{3}{*}{\multicolumn{2}{|c|}{$\begin{array}{l}\text { Maestrich- } \\
\text { tian }\end{array}$}} & \multirow{3}{*}{$\begin{array}{l}67 \\
68\end{array}$} & & $\begin{array}{l}\text { Micula } \\
\text { mura }\end{array}$ & & & 2 & $\begin{array}{l}11-6,30 \\
13-1,78\end{array}$ & & & & & \\
\hline & & & & & $\begin{array}{l}\text { Lithraphidites } \\
\text { quadratus }\end{array}$ & & & & & & & & & \\
\hline & & & & & $\begin{array}{l}\text { Arkhangskiella } \\
\text { cymbiformis }\end{array}$ & & & & $\begin{array}{l}13-2,125 \\
14-5,14\end{array}$ & & & & & \\
\hline $78-$ & \multicolumn{2}{|c|}{ Campanian } & \multirow[t]{2}{*}{71} & & $\begin{array}{l}\text { Tetralithus } \\
\text { trifidus }\end{array}$ & & & & $14-5,72$ & & 1 & & & \\
\hline 92 & \multicolumn{2}{|c|}{ 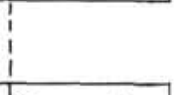 } & & & $\begin{array}{l}\text { Hiatus or Barren } \\
\text { in Leg } 44 \text { Sites }\end{array}$ & & & & \multirow{3}{*}{ Hiatus } & & Hiatus & & & \\
\hline \multirow[t]{2}{*}{100} & \multicolumn{2}{|c|}{ Cenomanian } & 97.5 & & Eiffellithus & & & & & & & & & \\
\hline & Albian & \multicolumn{2}{|c|}{$\begin{array}{l}104 \\
106.5\end{array}$} & & $\begin{array}{l}\text { Prediscosphaera } \\
\text { cretacea }\end{array}$ & & & & & & 2 & $\begin{array}{l}21 ? \\
\text { Barren }\end{array}$ & $\begin{array}{c}4-8 ? \\
\text { Barren }\end{array}$ & \\
\hline \multirow[t]{2}{*}{108} & \multirow{2}{*}{\multicolumn{2}{|c|}{ Aptian }} & \multirow{2}{*}{$\begin{array}{l}112 \\
115\end{array}$} & & $\begin{array}{l}\text { Parhabdolithus } \\
\text { angustus }\end{array}$ & & & $3-5$ & $\begin{array}{l}14-5,86 \\
14, \mathrm{CC} \\
\end{array}$ & & 3 & & $9-10 ?$ & \\
\hline & & & & & $\begin{array}{l}\text { Chiastozygus } \\
\text { litterarius }\end{array}$ & & & & & & & & 112 & \\
\hline 115 & \multirow{2}{*}{\multicolumn{2}{|c|}{ Barremian }} & \multirow{4}{*}{$\begin{array}{l}118 \\
124 \\
128.5\end{array}$} & & $\begin{array}{l}\text { Micrantholithus } \\
\text { hoschulzii }\end{array}$ & & & $5-6$ & & & 4 & & 11.12 & \\
\hline 121 & & & & & $\begin{array}{l}\text { Lithraphidites } \\
\text { bollii }\end{array}$ & & & & & & & & 120 & \\
\hline 126 & Hauterivian & & & & $\begin{array}{l}\text { Calcicalathina } \\
\text { oblongata }\end{array}$ & & & & & & & & $13-32$ & \\
\hline 131 & Valangin & & & & $\begin{array}{l}\text { Cretarhabdus } \\
\text { crenulatus }\end{array}$ & & & & & & & & $33-37$ & \\
\hline 135) & Berriasi: & & & & $\begin{array}{l}\text { Nannoconus } \\
\text { colomii }\end{array}$ & & & & & & & & $38-45$ & \\
\hline 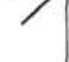 & & $* 1$ & 136.5 & & Parhabdolithus & & & & & & & & & \\
\hline & $\begin{array}{c}\text { Tithon- } \\
\text { ian }\end{array}$ & & 139.5 & & embergeri & & & & & & & & $46-54$ & \\
\hline 141 & meric & $\begin{array}{l}\text { Kim- } \\
\text { dgian }\end{array}$ & & & $\begin{array}{l}\text { Watznaueria } \\
\text { communis }\end{array}$ & & & & & & & & & \\
\hline
\end{tabular}

*Portlandian

arrangement of crossbars are also present in lowermost Paleocene samples. These specimens have fewer elements on the distal shield and the central area is almost entirely filled with the crossbars. These forms are designated Cruciplacolithus cf. C. tenuis in which the major axis of the ellipse ranges from 3 to 8 microns. The name Cruciplacolithus tenuis s.s. is confined to specimens larger than 8 microns. This limiting criterion is used to distinguish a Cruciplacolithus tenuis Zone in Core 390A-11; the zone definition may not conform to that of other authors who might place the boundary lower.

Similar small coccoliths and coccospheres of Toweius petalosus are very abundant in the Paleocene samples below the acme of Biscutum dimorphosum. The turnover in the two species, or at least in the relative dominance of the two species, is abrupt (Table 2). This suggests that Biscutum dimorphosum may have developed from Toweius petalosus. There is a trend, similar to that in the Cruciplacolithus tenuis group, in specimens of small Coccolithus sp. (2-5 microns) and more typical Coccolithus cavus (greater than 5 microns) to increase in size in successively higher samples of Core 390A-11.

\section{Markalius inversus Zone (NP 1)}

Definition: Braarudosphaera and Thoracosphaera plus the first Paleocene species to the first occurrence of Cruciplacolithus tenuis s.s.

Remarks: The base of the Markalius inversus Zone (NP 1) is generally defined as the interval from the last occurrence of Arkhangelskiella cymbiformis and other Cretaceous species. Because of widespread reworking of Cretaceous species in lower Paleocene sediments, this is an inadequate working definition. The Cretaceous-Tertiary boundary is first signaled by an acme of Braarudosphaera and Thoracosphaera species. Rarely occurring Biantholithus sparsus, Goniolithus fluckigeri, and Zygodiscus sigmoides are occasionally 
present at the boundary. At somewhat higher levels Cruciplacolithus $\mathrm{cf}$. C. tenuis (3-8 microns) and small Coccolithus sp. (2-5 microns) occur in increasing numbers. Although Markalius inversus occurs sporadically below the Cretaceous/Tertiary boundary, it first becomes conspicuous in lowermost Paleocene samples. Toweius petalosus, probably often confused with small Thoracosphaera species, first occurs abundantly just above the boundary (Table 2).

\section{SITE SUMMARIES}

\section{Site 388: Lower Continental Rise Hills}

Quaternary and middle-upper Miocene assemblages are present in the 11 cores recovered from Hole 388A.

\section{Quaternary (Cores 388A-1 to -3)}

Samples from the calcareous clay, sand, and silt of Cores $388 \mathrm{~A}-1$ to -3 contain abundant and wellpreserved nannofossils. Reworked nannoplankton also occur in these samples, particularly in those from the Upper Cretaceous. Upper Cretaceous species, all well preserved, include Cretarhabdus crenulatus, Lithastrinus floralis, Micula decussata, Prediscosphaera cretacea, Watznaueria barnesae and Zygodiscus diplogrammus. A few, poorly preserved specimens of reworked Tertiary species are also found, such as Reticulofenestra pseudoumbilica, Coccolithus miopelagicus, Discoaster barbadiensis, and Chiasmolithus sp.

Section 1 of Core 388A-1 is assigned to the combined Gephyrocapsa oceanica/Emiliana huxleyi zonal interval (NN 20/21) on the basis of abundant G. oceanica and the absence of Pseudoemiliania lacunosa. The corecatcher samples of Cores $388 \mathrm{~A}-1$ to -3 are assigned to the Pseudoemiliania lacunosa Zone (NN 19). The cooccurrence of the index species with Gephyrocapsa oceanica (and the absence of discoasters) delimits this lower Quaternary zone. Other Quaternary species consistently found in the cores mentioned above include Cyclococcolithus leptoporus, Coccolithus pelagicus, Helicosphaera carteri, Emiliania annula, Discolithina japonica, Syracosphaera histrica, and Ceratolithus cristatus.

\section{Miocene (Cores 388-A-4 to -11)}

After a gap of 144.5 meters, Cores $388 \mathrm{~A}-4$ to -11 penetrated middle-upper Miocene silty clays. All samples observed were deposited close to the carbonate compensation depth as indicated by the high discoaster/coccolith ratio and the etched and fragmented nature of the few coccoliths present. Relatively few specimens of coccoliths such as Reticulofenestra pseudoumbilica, Coccolithus pelagicus, Cyclococcolithus macintyrei, Sphenolithus abies, and, in the lower cores, Cyclicargolithus floridanus are identifiable. On the other hand, the discoasters are diverse and well preserved. The index species for the Discoaster quinqueramus Zone (NN 11), the D. calcaris Zone (NN 10), and the D. hamatus Zone (NN 11) were recognized in succession.

Samples from Cores 388A-4 and -6 contain Discoaster quinqueramus, restricted to the upper Miocene $D$. quinqueramus Zone (NN 11); samples from
Core 388A-5 are virtually barren of nannofossils. Samples from Cores $388 \mathrm{~A}-7,-8$, and the top of -9 (9-3, $116 \mathrm{~cm}$ ) are assigned to the upper Miocene Discoaster calcaris Zone (NN 10). Other discoasters present in these two zones include common $D$. brouweri, $D$. pentaradiatus, $D$. variabilis, $D$. intercalaris, and rare $D$. neoerectus.

The bottoms of Cores 388A-9, -10 , and -11 contain discoasters of the middle Miocene Discoaster hamatus Zone (NN 9). Besides the restricted index species, associated species include common Discoaster bollii and D. neohamatus, and rare D. pseudovariabilis and D. prepentaradiatus.

\section{Sites 389, 390, and 392: Blake Nose}

The objectives of Sites 389-390 and Site 392 (approximately $15 \mathrm{~km}$ south of Site 390 ) were to sample the reef-like limestones close to the sediment surface on the Blake Nose. At both locations, abundant to common and well-preserved nannofloras were recovered in the ooze above the indurated limestone. In addition to a thin veneer of Quaternary sediment, the ooze above the hard limestone contain middle Eocene to Upper Cretaceous (Barremian) nannofloras.

Nearly continuous coring in Hole 390A resulted in a well-documented section in which the Tertiary/Cretaceous boundary was recovered in Core 11 and a large unconformity between the upper Campanian and Albian was found in Core 14. The Albian to Barremian sediments were penetrated deeper in Holes 390 and $392 \mathrm{~A}$. The nannofossil biostratigraphy of Site 392 is comparable to that of Site 390 between the upper Campanian-Albian hiatus and the hard limestone.

Quaternary (Cores 389-1, 392-1, and 392-2)

The single, surface core recovered at Site 389 contains an upper Quaternary flora of the combined Gephyrocapsa oceanica-Emiliania huxleyi zonal interval (NN 20/21). Species presumed to be autochthonous include Gephyrocapsa oceanica, Cyclococcolithus leptoporus, Coccolithus pelagicus, Helicosphaera carteri, Emiliania annula, Oolithus antillarum, Rhabdosphaera stylifer, Syracosphaera histrica, and Ceratolithus cristatus.

A wide variety of well-preserved reworked species are also present. Common species from the Upper Cretaceous include Zygodiscus diplogrammus, Microrhabdulus decoratus, Chiastozygus amphipons, Manivitella pemmatoidea, among others. The middle Miocene-Pliocene interval contains Discoaster hamatus, D. neohamatus, Reticulofenestra pseudoumbilica, Coccolithus miopelagicus, D. brouweri, D. asymmetricus, D. tamalis, Sphenolithus abies, Ceratolithus rugosus, and Pseudoemiliania lacunosa. The displaced assemblages were probably derived from subsurface outcrops in the vicinity, the nannofossils having been winnowed out and redeposited by bottom currents.

The two surface cores of Hole 392 contained ooze with abundant nannofossils. The assemblages are dominated by displaced components. Core $392-2$ is probably upper Quaternary on the basis of the rare occurrence of Gephyrocapsa oceanica (NN 20/21) and the presence of other associated species mentioned 
TABLE 2

Distribution of Paleocene-Middle Eocene Nannoplankton of Holes 390, 390A From the Blake Nose

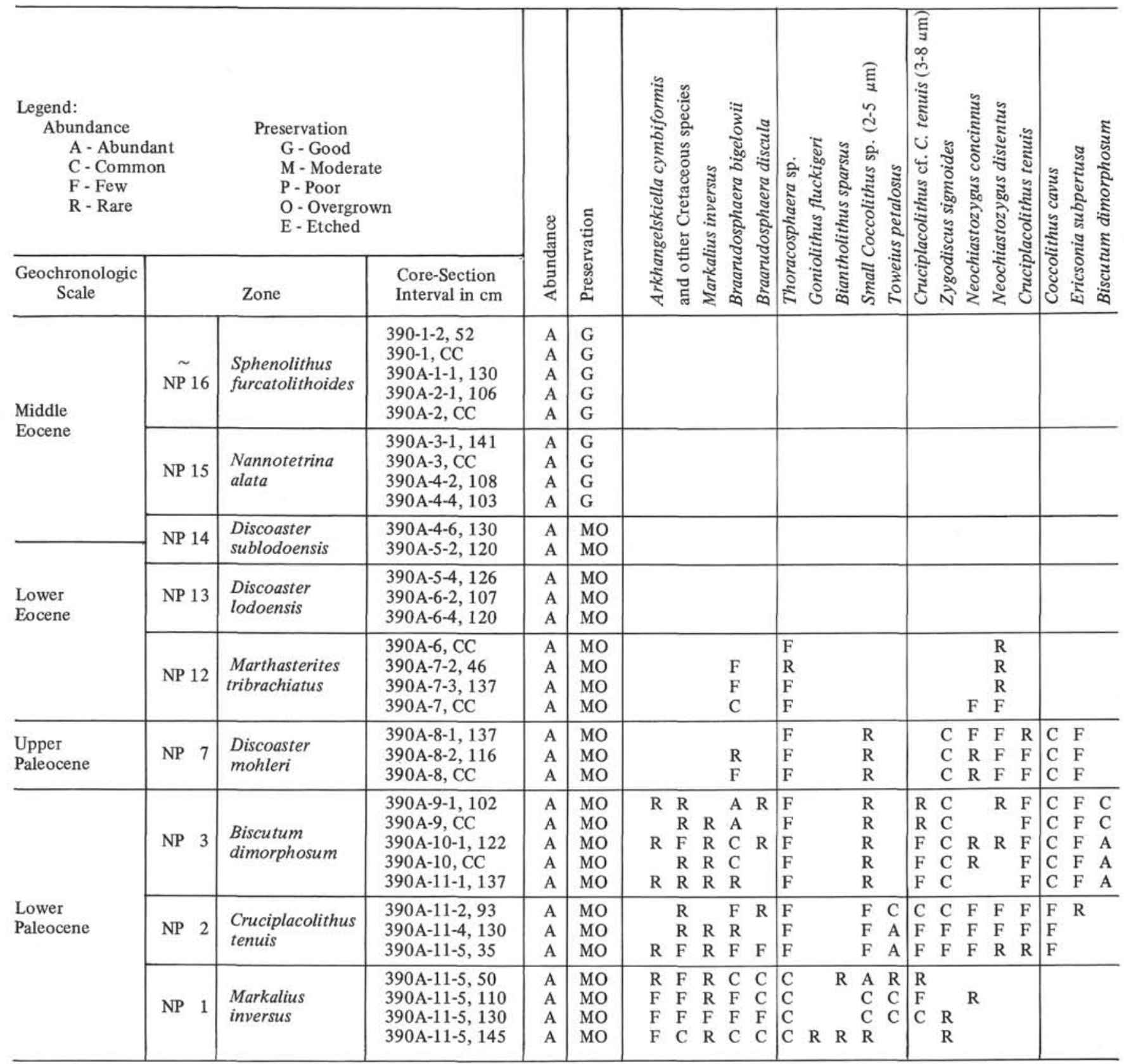

above. Displaced middle Eocene species are the dominant component of the assemblage. They include Sphenolithus furcatolithoides, Reticulofenestra umbilica, Chiphragmalithus grandis, Micrantholithus procerus, and Discoaster barbadiensis. A diverse and wellpreserved Cretaceous assemblage is also present and includes Parhabdolithus angustus, Manivitella pemmatoidea, Zygodiscus diplogrammus, and Nannoconus truittii. Probably the bulk of the carbonate in these cores was redeposited from middle Eocene and Cretaceous subsurface outcrops and/or artificially mixed in the drilling process.

\section{Eocene (390-1, 390A-1 to -7)}

Moderately well to well-preserved middle and lower Eocene nannofloras occur in the top cores of Holes 390 and 390A (see Table 2; Plate 2).

Samples in Cores 390-1 and 390A-1 and -2 are assigned to the Sphenolithus furcatolithoides Zone, which probably corresponds to the lower part of the Discoaster tani nodifer Zone (NP 16). Characteristic species for this zone include Chiasmolithus grandis, Micrantholithus procerus, Reticulofenestra umbilica, exceptionally long-rayed Sphenolithus furcatolithoides, and rare Chiasmolithus gigas, Discoaster tani, and 


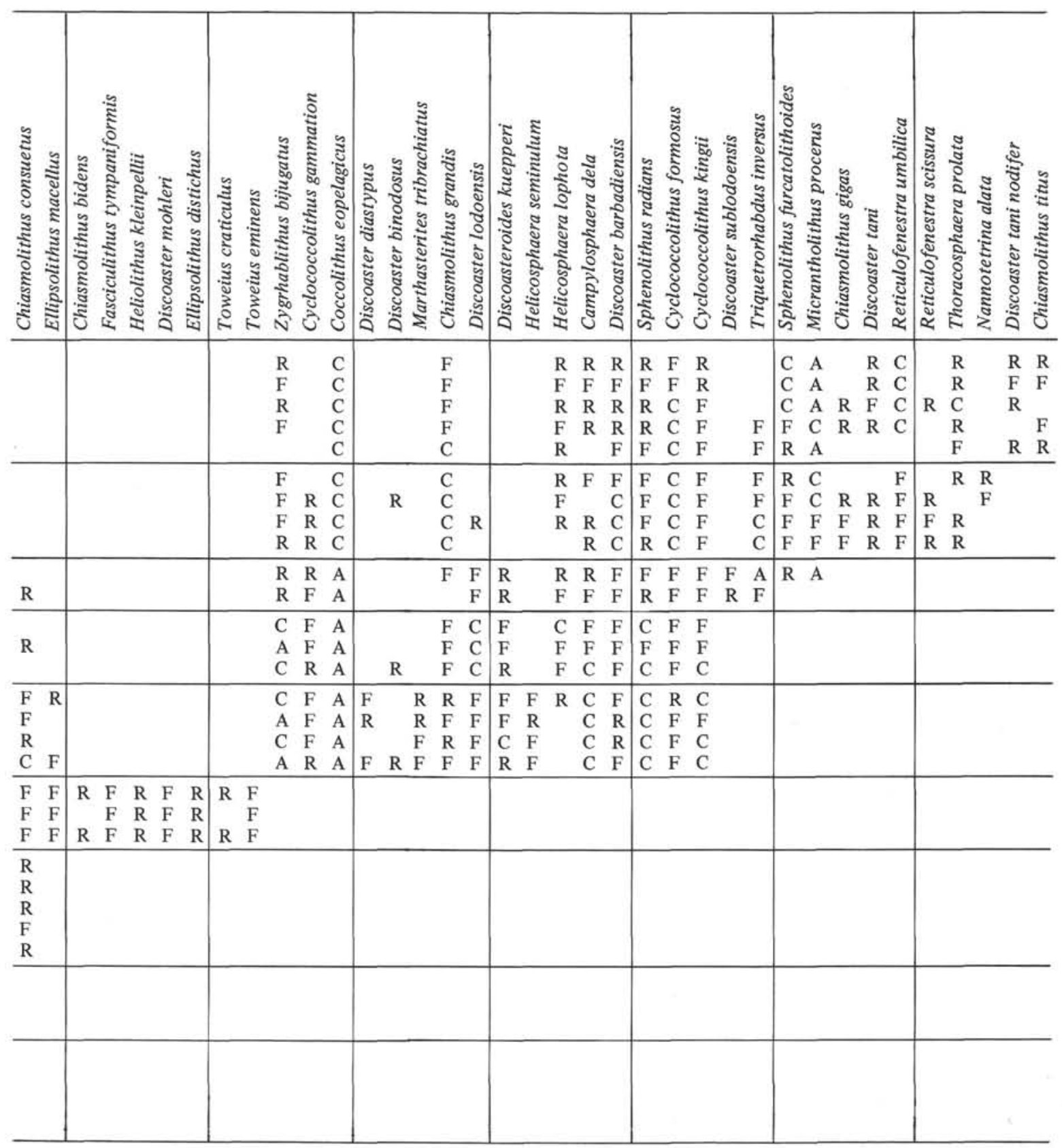

Thoracosphaera prolata. Chiasmolithus titus and Discoaster tani nodifer first occur in this middle Eocene zone.

Samples in Cores 390A-3 and -4 are assigned to the underlying middle Eocene Nannotetrina alata Zone (NP 15). The species composition is similar to that of the Sphenolithus furcatolithoides Zone with the addition of Nannotetrina alata. Chiasmolithus gigas, Discoaster tani, Reticulofenestra umbilica, $R$. scissura, and Thoracosphaera prolata first occur in the Nannotetrina alata Zone (NP 15).

Samples from the bottom of Core 390A-4 and the top of 390A-5 contain Discoaster sublodoensis, a characteristic species of the D. sublodoensis Zone (NP 14). Discoaster sublodoensis, Triquetrorhabdulus inversus, Sphenolithus furcatolithoides, and Micrantholithus procerus first occur, and Discoasteroides kuepperi last occurs in this lower/middle Eocene zone. Samples from the bottom of Core 390A-5 and the top of Core 390A-6 are assigned to the lower Eocene Discoaster lodoensis Zone (NP 13). The nannofloras have a different character in that many middle Eocene marker species noted above no longer are present (see Table 2).

Samples from the bottom of Core 390A-6 and Core 390A-7 contain the joint occurrence of Discoaster 
lodoensis and Marthasterites tribrachiatus indicative of the lower Eocene $M$. tribrachiatus Zone (NP 12). Campylosphaera dela, Cyclococcolithus gammation, Discoaster barbadiensis, D. lodoensis, Discoasteroides kuepperi, and Sphenolithus radians are some other characteristic species found in the Marthasterites tribrachiatus/Discoaster lodoensis zonal interval (NP $12 / 13)$. In addition to the last occurrence of Marthasterites tribrachiatus, the lower boundary of the Discoaster lodoensis Zone (NP 13) is approximately marked by the first occurrence of Helicosphaera lophata and the last occurrence of Discoaster diastypus.

\section{Paleocene (Cores 390A-8 to -11 )}

Nannofossils are abundant and moderately well preserved in the nannofossil ooze of Hole $390 \mathrm{~A}$, Cores 8 to $10,11-1$ to $11-5,145 \mathrm{~cm}$ (see Table 2; Plates 1 and 2). Reworked Upper Cretaceous species are present in all samples studied from the Paleocene sediments.

Samples from Core 390A-8 are included in the upper Paleocene Discoaster mohleri Zone (NP 7). This assemblage is characterized by the presence of Discoaster mohleri, Heliolithus kleinpellii, Fasciculithus tympaniformis, and Toweius craticulus, and the absence of Discoaster multiradiatus and $D$. nobilis from the overlying D. multiradiatus Zone (NP 18). Uppermost Paleocene and the lowermost Eocene sediments (as represented by Zones NP 8 through 11) may be missing at Hole $390 \mathrm{~A}$. If present they must occur within the 10 meter interval between Cores 7 and 8 , and thus were deposited at a much reduced rate. Similarly, there is a break in coverage between Cores 8 and 9 in which Zones NP 4 to 6 may represent the middle Paleocene interval.

Cores 390A-9, -10 , and the top of -11 are assigned to the Biscutum dimorphosum Zone, which probably correlates to the Chiasmolithus danicus (Danian or lower Paleocene) Zone (NP 3). The first occurrences of Biscutum dimorphosum (abundant) and Chiasmolithus consuetus (rare) and the absence of Ellipsolithus macellus and Fasciculithus tympaniformis define the limits of this zone.

The lowermost two zones in the Paleocene occur between 390A-11-2, $93 \mathrm{~cm}$ and 390A-11-5, $145 \mathrm{~cm}$ (see Table 2). Commonly occurring Toweius petalosus, Braarudosphaera spp., and Thoracosphaera spp. and rarely occurring Biantholithus sparsus, Goniolithus fluckigeri, and Zygodiscus sigmoides characterize this interval. The boundary between the Markalius inversus Zone (NP 1) and the Cruciplacolithus tenuis Zone (NP 2 ) is recognized by the level at which Cruciplacolithus tenuis is larger than 8 microns. A smaller form referred to as Cruciplacolithus $\mathrm{cf}$. C. tenuis (3-8 microns) occurs lower in the Markalius inversus Zone. Similarly, typical Coccolithus cavus and Ericsonia subpertusa first occur in the samples referred to the Cruciplacolithus tenuis Zone (NP 2).

The Tertiary/Cretaceous boundary occurs at 390A$11,145 \mathrm{~cm}$, in clayey nannofossil ooze and is marked by a color change from light gray to light bluish or greenish gray (boundary between lithologic Units 4 and $5)$. The nannoflora is marked by a notable change in preservation and by an acme of Braarudosphaera and Thoracosphaera and the rare occurrence of a few Paleocene species mentioned above. Diverse and well preserved reworked Maestrichtian nannofloras occur together with the less well-preserved Danian (in place) nannofloras.

\section{Upper Cretaceous (Cores 390-2; 390A-11 to -14; 392A-1)}

Upper Campanian-Maestrichtian nannofloras were recovered from Sites 390 and 392, especially from the nearly complete section in Hole 390A. The nannofossils are well to moderately well preserved and are assigned to three nannoplankton zones (see Table 3; Plates 3-5).

The upper Maestrichtian Micula mura Zone is recognized in the bottom of Cores $390 \mathrm{~A}-11,-12$, and the top of -13 , and in Core 390-2. In the sections above, the zone is characterized by the first occurrences of Lithraphidites quadratus, Micula mura, and Ceratolithoides kamptneri. Another index species, restricted to this zone, Nephrolithus frequens, occurs rarely in Sample 390A-11, CC. Only the short-rayed form of Micula mura is present, which indicates that the uppermost Maestrichtian part of the zone is not represented in this section. A possible small hiatus at the Tertiary/Cretaceous boundary is also indicated by the absence of the Abathomphalus mayaroensis planktonic foraminifer zone.

Samples from the bottom of Cores 390A-13 and -14 (to $390 \mathrm{~A}-14-5,14 \mathrm{~cm}$ ) are referred to the Arkhangelskiella cymbiformis Zone (sensu Martini, 1976). This zone comprises the interval from the last occurrence of Tetralithus trifidus to the first occurrence of Lithraphidites quadratus. The Lithraphidites quadratus Zone (sensu Martini, 1976) is the interval between the first occurrence of Lithraphidites quadratus to the first occurrence of Micula mura. In Sample 390A-13-1, $78 \mathrm{~cm}$ the latter two index species occur together and coincide with a distinct lithologic change. A possible "middle" Maestrichtian hiatus is substantiated by missing planktonic foraminifer zones at the same level.

A short section of upper Campanian nannofossil ooze was recovered from the base of Core 390A-14 (Section 5, 50-80 cm) and from Core 392A-1. The cooccurrence of Tetralithus gothicus, $T$. trifidus, Lucianorhabdus cayeuxii, and Eiffellithus eximius is indicative for the Tetralithus trifidus Zone.

Lower Cretaceous (Cores 390-3 to -6 ; 390A-14; 392A-2 to -4 )

A hiatus of considerable duration was detected at Sample $390 \mathrm{~A}-14-5,80 \mathrm{~cm}$. It is bounded by upper Campanian and lower Albian nannofossil ooze. Nannofossils of the Parhabdolithus angustus Zone are abundant and moderately well preserved in Samples $390 \mathrm{~A}-14-5,122 \mathrm{~cm}$ and $-14-5, \mathrm{CC}$ and in Cores 390-3,-4, and the top of -5. This upper Aptian to lower Albian zone is defined by the first occurrences of Parhabdolithus angustus and Lithastrinus floralis before the occurrence of Prediscosphaera cretacea. Parhabdolithus angustus, Flabellites biforaminis, Corollithion achylosum, Tranolithus gabalus, and Braarudosphaera africana occur in these samples. All of these species have their first recorded occurrences in the Parhabdolithus angustus Zone. 
Core 392A-2, from the other site on the Blake Nose, contains the Albian Prediscosphaera cretacea Zone. This is indicated by the co-occurrence of Prediscosphaera cretacea (rare), Braarudosphaera africana, Hayesites albiensis, Tranolithus exiguus, and Corollithion achylosum. Core 392A-3 is assigned to the upper Aptian to lower Albian Parhabdolithus angustus Zone. Diagnostic species present include Parhabdolithus angustus, Lithastrinus floralis, Rucinolithus irregularis, and Nannoconus truittii. Core 392-4 contains a well-preserved assemblage assigned to the Barremian Micrantholithus hoschulzii Zone. Characteristic species include Micrantholithus hoschulzii, M. obtusus (rare), Hayesites atlanticus, Reinhardtites fenestratus, and Nannoconus colomii (abundant). An increasing abundance of nannoconids in Cores 392A-2 to -4 may indicate progressively shallower water depositional environments in progressively older sediments (Albian-Barremian).

Deeper in Hole 390, abundant, but not very wellpreserved, nannofloras in Samples 390-5, CC and -6, $\mathrm{CC}$ are assigned to the Barremian Micrantholithus hoschulzii Zone. The presence of Micrantholithus hoschulzii, M. obtusus, Reinhardtites fenestratus, and abundant Nannoconus colomii, in the absence of Chiastozygus litterarius and Rucinolithus irregularis, suggests the assignment to the Micrantholithus hoschulzii Zone. Samples from Cores $390-8$ and -9 in the limestone unit did not contain nannofossils.

\section{Sites 391, 393, 394: Blake-Bahama Basin}

Quaternary and Miocene nannofossil assemblages have been identified in the upper cores of Site 391 and Sites 393 and 394. The most continuous section of the Quaternary silty clay and Miocene intraclastic chalk and mudstone was recovered from Hole 391A (Cores 320). An extensive section of Upper Jurassic and Lower Cretaceous sediment was recovered from greater depths in Hole 391C. Mid-Cretaceous dark claystone lies unconformably on Miocene chalk breccia. No calcareous nannoplankton occur in the upper part of the sequence (Cores 391A-21, 391C-4 to -8). Moderately well-preserved calcareous nannoplankton are common from Cores 391C-9 to -54-an almost continuously cored sequence. This sequence comprises a succession of lower Tithonian (or upper Kimmeridgian) to lower Albian nannofossil zones, or a combination of two zones.

\section{Quaternary (Cores 391-1; 391B-1; 391A-1 to -3; 391C-1)}

The uppermost cores are nannofossil ooze and contain generally well-preserved but sometimes etched nannofossils. Cores 391-1 and 391B-1 are assigned to the upper Quaternary combined Gephyrocapsa oceanica/Emiliania huxleyi zonal interval (NN 20/21). The presence of Gephyrocapsa oceanica, Syracosphaera histrica, Rhabdosphaera clavigera, Ceratolithus cristatus, and, perhaps, Emiliania huxleyi indicates that these are upper Pleistocene-Recent sediments.

The assemblage of Sample 391A-2, CC is similar to the above, but contains also a few Pseudoemiliania lacunosa. Reworked Pliocene nannofossils do occur in all Quaternary samples as indicated by the presence of
Discoaster surculus, D. pentaradiatus, D. brouweri, Sphenolithus abies, and Reticulofenestra pseudoumbilica. Pseudoemiliania lacunosa may also have been introduced in Sample 391A-2, CC by reworking. Because of this uncertainty, I assigned the sample to the combined Pseudoemiliania lacunosa/Gephyrocapsa oceanica zonal interval (NN 19/20).

Samples 391A-1, CC and 391A-3-1, $140 \mathrm{~cm}$ are assigned to the lower Quaternary Pseudoemiliania lacunosa Zone (NN 19). They contain the index species and Gephyrocapsa spp. Pliocene discoasters, Sphenolithus abies, and Reticulofenestra pseudoumbilica persist as minor contaminants in the assemblage.

Core 391C-1 is Quaternary nannofossil ooze. The age was established by the presence of abundant Pseudoemiliania lacunosa and Gephyrocapsa spp. Pliocene contaminants are present and include Discoaster asymmetricus, D. surculus, D. brouweri, D. pentaradiatus, Sphenolithus abies, and perhaps even Pseudoemiliania lacunosa. Down-hole caving surely contaminated the interval between 335.5-345 meters.

Miocene (Cores 391A-3 to -20 ; 391C-2 to -3 ; 394A-5 to -6 )

Miocene chalk and intraclastic chalk from the BlakeBahama Basin contain reworked Eocene-Oligocene and Upper Cretaceous species. Both the in place and displaced species are overgrown, often to the extent that identification is impossible. The discoasters are especially overgrown. I relied mostly upon the last occurrences of index species to date such potentially mixed assemblages.

The mudstone contains nannofossils that are well preserved and sometimes show dissolution features. Mudstone clasts in the chalk have fewer reworked specimens. Some of the mudstone inclusions contain no nannofossils but are rich in siliceous debris. The majority of the chalk matrix, including the Eocene and Upper Cretaceous constituents, were derived from shelf or plateau deposits transported to the basin. The mudstone inclusions, some of which are radiolarianrich, are probably clasts of the basin sediments which had been deposited just below the carbonate compensation depth (CCD). Much of the mud lying on the basin floor was disrupted by some kind of gravity flow and was redeposited as clasts in a chalk matrix farther basinward.

Samples 391A-3, CC and 391A-4-1, $112 \mathrm{~cm}$ from light-colored chalks contain poorly preserved nannofossils of the upper Miocene Discoaster quinqueramus Zone (NN 11). Five-rayed, overgrown discoasters are abundant; because some specimens are better preserved in the upper sample, these could be identified as Discoaster quinqueramus. Amaurolithus tricorniculatus is also present; its first occurrence being from the $D$. quinqueramus Zone. Other identified species associated with this zone include Sphenolithus abies, D. variabilis, D. pentaradiatus, D. brouweri, and (rare) D. surculus.

In samples 391A-5, CC and 391A-6, CC, the discoasters and many of the coccoliths are overgrown to the extent that recognition of species, except for resistant, long-ranging ones, is difficult. As the 
TABLE 3

Distribution of Cretaceous Nannoplankton of Hole 390A from the Blake Nose

\begin{tabular}{|c|c|c|c|c|c|c|c|c|c|c|c|c|c|c|c|}
\hline \multicolumn{2}{|c|}{$\begin{array}{l}\text { Legend: } \\
\text { Abundance } \\
\text { A - Abundant } \\
\text { C - Common } \\
\text { F - Few } \\
\text { R - Rare }\end{array}$} & \multicolumn{2}{|c|}{$\begin{array}{l}\text { Preservation } \\
\text { G - Good } \\
\text { M - Moderate } \\
\text { P - Poor } \\
\text { O- Overgrown } \\
\text { E- Etched }\end{array}$} & \multirow{2}{*}{ 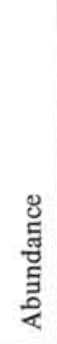 } & \multirow{2}{*}{ 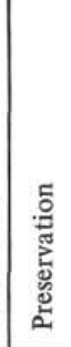 } & \multirow{2}{*}{ 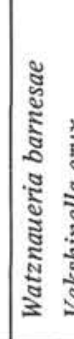 } & \multirow{2}{*}{\multicolumn{2}{|c|}{ 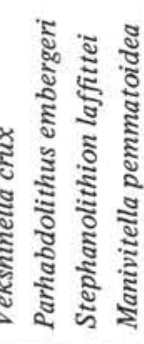 }} & \multirow{2}{*}{ 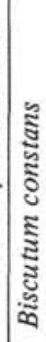 } & \multirow{2}{*}{ 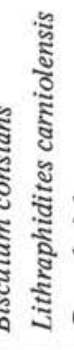 } & \multirow{2}{*}{ 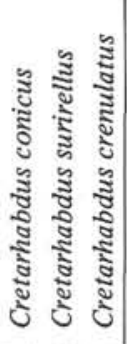 } & \multirow{2}{*}{ 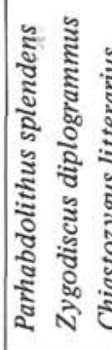 } & \multirow{2}{*}{ 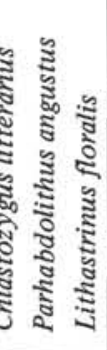 } & \multirow{2}{*}{ 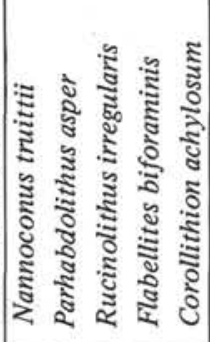 } & \multirow{2}{*}{ 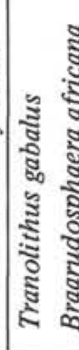 } \\
\hline $\begin{array}{c}\text { Geochronologic } \\
\text { Scale }\end{array}$ & & Zone & $\begin{array}{c}\text { Core-Section } \\
\text { (Interval in } \mathrm{cm} \text { ) }\end{array}$ & & & & & & & & & & & & \\
\hline $\begin{array}{l}\text { Upper } \\
\text { Maestrichtian }\end{array}$ & & $\begin{array}{l}\text { icula } \\
\text { iura }\end{array}$ & $\begin{array}{l}390 \mathrm{~A}-11-6,30 \\
390 \mathrm{~A}-11, \mathrm{CC} \\
390 \mathrm{~A}-12-4,67 \\
390 \mathrm{~A}-12, \mathrm{CC} \\
390 \mathrm{~A}-13-1,78\end{array}$ & $\begin{array}{l}\text { A } \\
\text { A } \\
\text { A } \\
\text { A } \\
\text { A }\end{array}$ & $\begin{array}{l}\text { G } \\
\text { G } \\
\text { G } \\
\text { G } \\
\text { G }\end{array}$ & $\begin{array}{ll}\mathrm{C} & \mathrm{C} \\
\mathrm{C} & \mathrm{C} \\
\mathrm{C} & \mathrm{F} \\
\mathrm{A} & \mathrm{F} \\
\mathrm{C} & \mathrm{F}\end{array}$ & $\begin{array}{l}R \\
F \\
F \\
F \\
F\end{array}$ & $\begin{array}{ll}\mathrm{F} & \mathrm{R} \\
\mathrm{F} & \mathrm{F} \\
\mathrm{F} & \mathrm{F} \\
\mathrm{F} & \mathrm{F} \\
& \mathrm{F}\end{array}$ & $\begin{array}{l}F \\
F \\
F \\
F \\
F\end{array}$ & $\begin{array}{l}\mathrm{F} \\
\mathrm{F} \\
\mathrm{F} \\
\mathrm{C} \\
\mathrm{F}\end{array}$ & $\begin{array}{lll}\mathrm{F} & \mathrm{R} & \mathrm{C} \\
\mathrm{F} & \mathrm{R} & \mathrm{C} \\
\mathrm{F} & & \mathrm{C} \\
\mathrm{F} & \mathrm{R} & \mathrm{C} \\
\mathrm{R} & & \mathrm{C}\end{array}$ & $\begin{array}{lll}\mathrm{F} & \mathrm{R} & \mathrm{R} \\
\mathrm{F} & \mathrm{F} & \mathrm{F} \\
\mathrm{F} & \mathrm{F} & \mathrm{F} \\
\mathrm{F} & \mathrm{F} & \mathrm{F} \\
\mathrm{F} & & \mathrm{R}\end{array}$ & $\begin{array}{ll}R & R \\
F & F \\
F & F \\
F & R \\
R & R\end{array}$ & & \\
\hline $\begin{array}{l}\text { Lower } \\
\text { Maestrichtian }\end{array}$ & & $\begin{array}{l}\text { rkhangelskiella } \\
\text { mbiformis }\end{array}$ & $\begin{array}{l}390 \mathrm{~A}-13-3,94 \\
390 \mathrm{~A}-13-5,85 \\
390 \mathrm{~A}-13, \mathrm{CC} \\
390 \mathrm{~A}-14-1,23 \\
390 \mathrm{~A}-14-3,140 \\
390 \mathrm{~A}-14-5,14\end{array}$ & $\begin{array}{l}\text { A } \\
\text { A } \\
\text { A } \\
\mathrm{A} \\
\mathrm{A} \\
\mathrm{A}\end{array}$ & $\begin{array}{l}\text { MO } \\
\text { MO } \\
\text { MO } \\
\text { MO } \\
\text { MO } \\
\text { MO }\end{array}$ & $\begin{array}{ll}\mathrm{A} & \mathrm{F} \\
\mathrm{A} & \mathrm{F} \\
\mathrm{C} & \mathrm{C} \\
\mathrm{A} & \\
\mathrm{A} & \\
\mathrm{C} & \\
\end{array}$ & $\begin{array}{l}\mathrm{F} \\
\mathrm{F} \\
\mathrm{F} \\
\mathrm{F} \\
\mathrm{F} \\
\mathrm{R}\end{array}$ & & $\begin{array}{l}F \\
F \\
R \\
R \\
R\end{array}$ & $\begin{array}{l}F \\
F \\
F \\
F \\
R \\
C\end{array}$ & $\begin{array}{lll}\mathrm{R} & \mathrm{R} & \mathrm{C} \\
\mathrm{R} & \mathrm{R} & \mathrm{C} \\
\mathrm{F} & \mathrm{F} & \mathrm{A} \\
\mathrm{R} & \mathrm{F} & \mathrm{A} \\
\mathrm{R} & & \mathrm{A} \\
\mathrm{F} & \mathrm{F} & \mathrm{C} \\
\end{array}$ & $\begin{array}{lll}\text { C } & F & F \\
F & R & F \\
F & F & \\
F & F & \\
F & R & F \\
R & F & R \\
\end{array}$ & $\begin{array}{ll}F & F \\
F & F \\
& F \\
& F \\
F & F \\
R & F\end{array}$ & & \\
\hline Upper Camp. & & trifidus & $390 A-14-5,72$ & A & MO & A $R$ & F & $\mathrm{C}$ & $\mathrm{F}$ & $F$ & $\mathrm{~A}$ & R $\quad$ C $\quad R$ & & & \\
\hline $\begin{array}{l}\text { Lower Albian } \\
\text { Upper Aptian }\end{array}$ & & $\begin{array}{l}\text { arhabdolithus } \\
\text { igustus }\end{array}$ & $\begin{array}{l}390 \mathrm{~A}-14-5,122 \\
390 \mathrm{~A}-14, \mathrm{CC}\end{array}$ & $\begin{array}{l}\mathrm{A} \\
\mathrm{A}\end{array}$ & $\begin{array}{l}\text { MO } \\
\text { MO }\end{array}$ & $\begin{array}{ll}\text { A } & \text { R } \\
\text { A } & \text { F }\end{array}$ & $\begin{array}{l}\mathrm{F} \\
\mathrm{C}\end{array}$ & $\begin{array}{ll}\text { F } & F \\
R & F\end{array}$ & C & $\begin{array}{l}\mathrm{C} \\
\mathrm{C}\end{array}$ & $\begin{array}{lll}R & F & F \\
& F & F\end{array}$ & $\begin{array}{lll}F & C & F \\
F & F & F\end{array}$ & $\begin{array}{lll}\mathrm{F} & \mathrm{R} & \mathrm{R} \\
\mathrm{F} & \mathrm{R} & \mathrm{F}\end{array}$ & $\begin{array}{lllll}\mathrm{R} & \mathrm{A} & \mathrm{F} & \mathrm{R} & \mathrm{F} \\
\mathrm{F} & \mathrm{C} & \mathrm{F} & \mathrm{F} & \mathrm{F}\end{array}$ & $\begin{array}{ll}\mathrm{R} & \mathrm{F} \\
\mathrm{R} & \mathrm{F}\end{array}$ \\
\hline
\end{tabular}

discoasters are the most important element for the zonation in the middle Miocene interval, no age assignment on the basis of nannoplankton is given. The few identifiable specimens of Sphenolithus heteromorphus, Discoaster exilis, and $D$. challengeri are probably derived from mudstone of an older age, as described below.

Well-preserved nannofossils occur in samples from a green mudstone (391A-7, CC and 391A-8-1,37 cm). An assemblage of Sphenolithus heteromorphus, $S$. moriformis, Cyclicargolithus floridanus, Discoaster exilis, and $D$. challengeri indicates the samples are from the middle/lower Miocene Sphenolithus heteromorphus Zone (NN 5). A sample from the bluish mudstone in the lower part of Core 8 (391A-8, CC) contains an older assemblage assignable to the lower Miocene Discoaster druggii Zone (NN 2). Besides the index species, other associated index markers include Triquetrorhabdulus carinatus, Discoaster deflandrei and Sphenolithus belemnos; all are well preserved, but some of the coccoliths are somewhat etched. This sample comes from a layer in the core that is probably part of a large clast which had been reworked into younger sediments of the Sphenolithus heteromorphus Zone (NN 5). The Sphenolithus heteromorphus Zone sediments occur both above and below the older layer. Small clasts of the same color also occur in Cores 391A-9 to -12 .

Samples from Cores 391A-9 to -11 belong to the lower/middle Miocene Sphenolithus heteromorphus Zone (NN 5). These samples also contain reworked species from the middle Eocene-Oligocene, such as Discoaster barbadiensis, Reticulofenestra umbilica, Sphenolithus furcatolithoides, Micrantholithus procerus, Chiasmolithus spp., Zygrhablithus bijugatus,
Sphenolithus ciperoensis, Helicosphaera recta, and Ericsonia fenestrata. Upper Cretaceous species are also present and include Prediscosphaera cretacea, Cretarhabdus conicus, Tetralithus aculeus, and Microrhabdulus decoratus. The preservation in these samples is poor; the discoasters and many of the coccoliths are overgrown. Index species such as Sphenolithus belemnos, Discoaster druggii, and Triquetrorhabdulus carinatus are sometimes present, but are reworked from the pulverization of an older mudstone (as in Sample 391A-8, CC).

Samples from Cores 391A-12 and -13 are assigned to the lower Miocene Helicosphaera ampliaperta Zone (NN 4). In addition to the nannoflora as above, they also contain $H$. ampliaperta (rare). Sample 391A-14, CC contains Sphenolithus belemnos (common) but no $H$. ampliaperta and Triquetrorhabdulus carinatus. Consequently, this rather poorly preserved sample is assigned to the lower Miocene Sphenolithus belemnos Zone (NN 3), which also contains Eocene and Upper Cretaceous reworked species.

Samples 391A-17, CC and -19, CC contain nannofossils of the lower Miocene Discoaster druggii Zone (NN 2). Triquetrorhabdulus carinatus, Discoaster druggii, and Sphenolithus belemnos (in Core 17) occur in these samples. Because Discoaster druggii is absent, Sample 391A-20 is assigned to the underlying lower Miocene Triquetrorhabdulus carinatus Zone (NN 1). By far the best preservation is found in the mudstone of Sample 391A-17, CC; the discoasters are not overgrown and include Discoaster deflandrei (abundant) and D. druggii (rare). Sample 391A-19, CC contains a few Eocene reworked species, and 391A-20, $\mathrm{CC}$ has both Oligocene-Eocene and Upper Cretaceous 


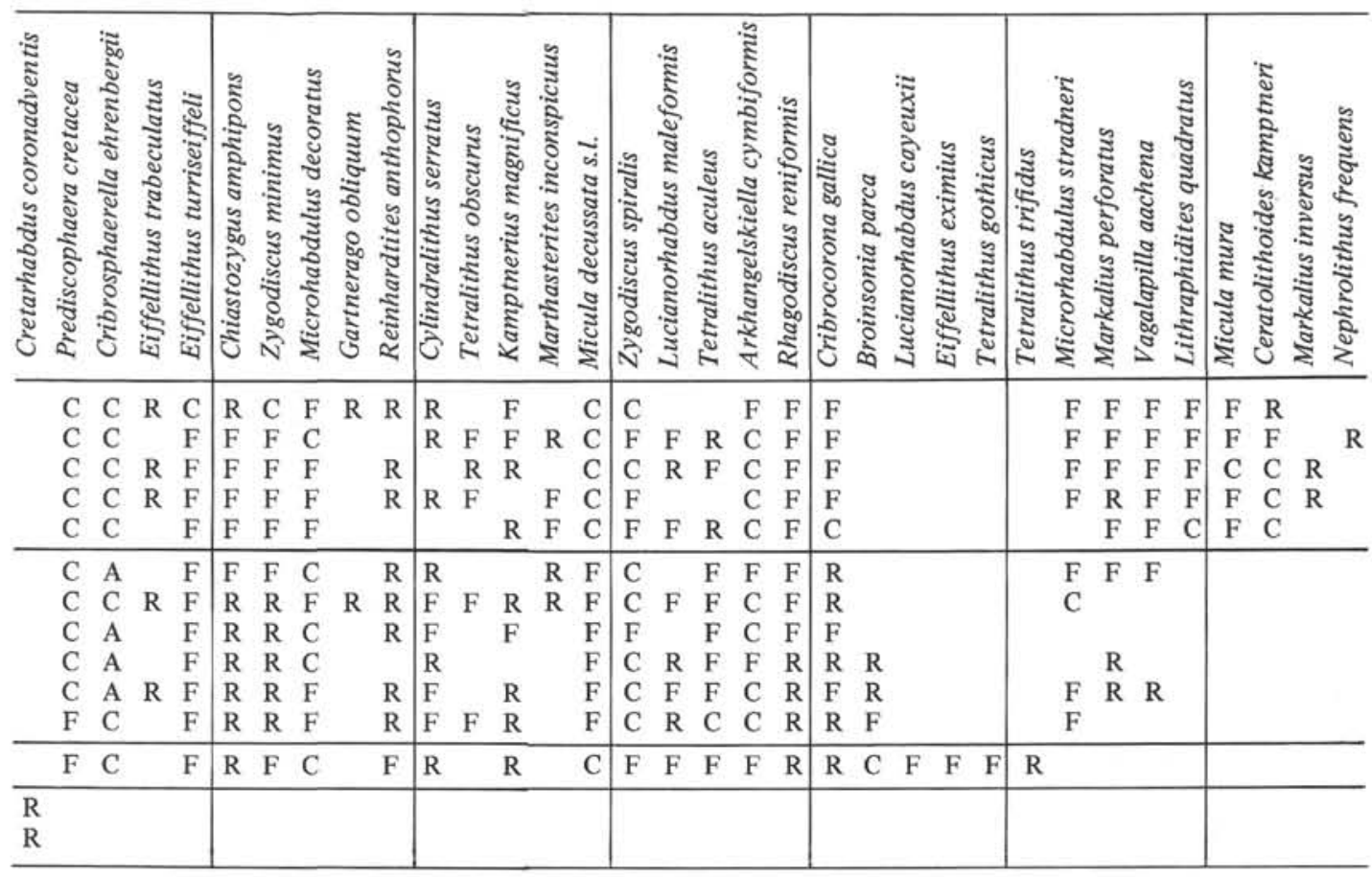

reworked species. Samples 391A-16, CC and -18, CC are from mudstone intervals that contain no nannofossils but large amounts of siliceous debris.

Spot cores from Hole 391C (391-2 and -3) contain abundant, but poorly preserved nannofossils and the assemblage contains many reworked Eocene species. The presence of Sphenolithus heteromorphus, $S$. moriformis, Discoaster deflandrei, Cyclicargolithus floridanus, and Helicosphaera intermedia indicates that they comprise lower/middle Miocene sediments (Helicosphaera ampliaperta/Sphenolithus heteromorphus zones, $\mathrm{NN} \mathrm{4/5).}$

The deepest cores from Site 394 (Leg 44A, BlakeBahama Basin) contain nannofloras of the middle/lower Miocene Sphenolithus heteromorphus Zone (NN 5). The nannofossils from Cores 394A-5 and -6 (marly chalk, sometimes with intraclasts), are poorly preserved and minor amounts of reworked OligoceneEocene specimens are present; a sample from a radiolarian mudstone $(394 \mathrm{~A}-6-6,118 \mathrm{~cm})$ is much better preserved. Sphenolithus heteromorphus, $S$. moriformis, Discoaster exilis, D. variabilis, $D$. deflandrei, D. challengeri, Cyclicargolithus floridanus, and Reticulofenestra pseudoumbilica are characteristic middle/lower Miocene species found in these samples.

\section{Upper Jurassic-Mid-Cretaceous (Cores 391C-9 to -54)}

Below the barren interval of Cores 391C-4 to -8 , the first carbonate-bearing layers occur intermittently in Cores 391C-9 and -10, in lighter colored grayish claystone. An assemblage of well-preserved, but sometimes etched nannofossils is found in these layers, and they were probably deposited just above the CCD for nannoplankton. Sample 391C-9-2, $48 \mathrm{~cm}$ belongs to the upper Aptian-lower Albian Parhabdolithus angustus Zone (see Table 4). This is indicated by the presence of Parhabdolithus angustus, Lithastrinus floralis, Flabellites biforaminis, Corollithion achylosum, and Tranolithus gabalus below the first occurrence of Prediscosphaera cretacea.

Samples from Cores $391 \mathrm{C}-10$ to -12 are assigned to the upper Barremian to lower Aptian Micrantholithus hoschulzii/Chiastozygus litterarius zonal interval. This zonal interval is the interval between the last occurrences of Calcicalathina oblongata and Cruciellipsis cuvillieri and the first occurrences of Parhabdolithus angustus and Lithastrinus floralis. The boundary between the Chiastozygus litterarius and Micrantholithus hoschulzii zones is marked by the first occurrences of Chiastozygus litterarius and/or Rucinolithus irregularis. These two rather delicate species are difficult to distinguish in assemblages of partially dissolved nannofossils as in Cores 391C-10 and -11 .

Samples from Cores $391 \mathrm{C}-13$ to -32 are assigned to the upper Valanginian to lower Barremian Calcicalathina oblongata/Lithraphidites bollii zonal interval. This zonal interval is characterized by the first occurrences of Calcicalathina oblongata, Podorhabdus dietzmannii, Zygodiscus diplogrammus, Parhabdolithus splendens, and Parhabdolithus infinitus and the last occurrences of Calcicalathina oblongata, Cruciellipsis cuvillieri, and Biopodorhabdus colligatus (see Table 4).

The Calcicalathina oblongata/Lithraphidites bollii zonal interval can be divided only roughly into the two component zones in Hole 391C. The index species, Lithraphidites bollii, which is restricted to the zone which bears its name, occurs in Core 391C-16 and may 
TABLE 4

Distribution of Uppermost Jurassic-Lower Cretaceous Nannoplankton of Hole 391C in the Blake-Bahama Basin

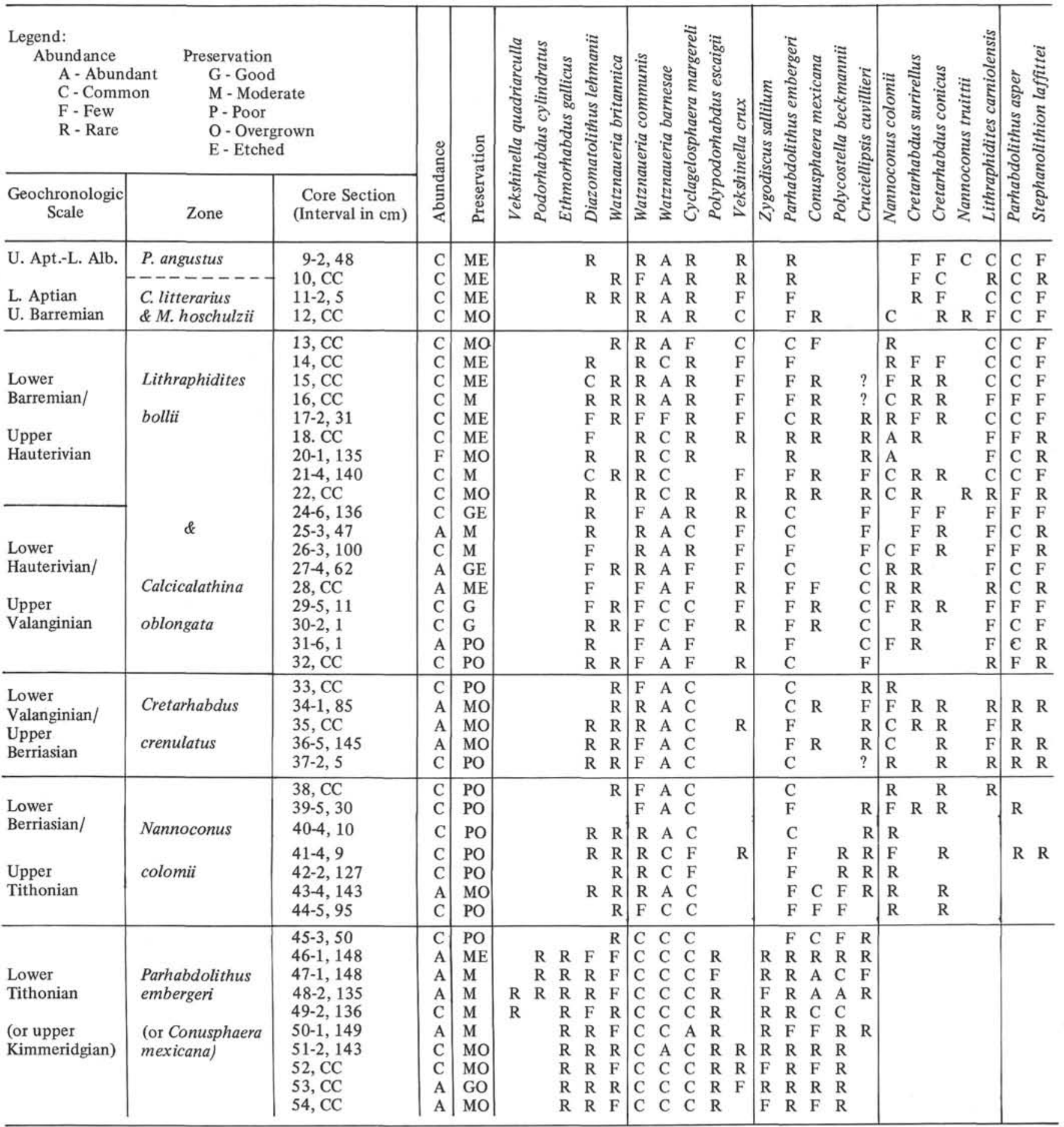

occur in Cores 391C-15, -17, and -21 (see Table 4). Tegumentum stradneri and Hayesites atlanticus, other species which first occur in the Lithraphidites bollii Zone are scattered throughout approximately the same interval. The lower part of this zonal interval is distinguished by the co-occurrence of Tubodiscus verenae and Calcicalathina oblongata, and the sporadic presence of Rucinolithus wisei, in Cores 391C-25 to -32. This is similar in concept to the Tubodiscus jurapelagicus Zone (Roth, 1973) and is roughly equivalent in age with the upper Valanginian to lower Hauterivian Calcicalathina oblongata Zone (Thierstein, 1971, 1973). The overlying upper Hauterivian to lower Barremian Lithraphidites bollii Zone is present but its boundaries, on the basis of the total range of Lithraphidites bollii, are too indefinite to allow its treatment as a separate zone (see Table 4).

Samples from Cores $391 \mathrm{C}-33$ to -37 are assigned to the upper Barremian to lower Valanginian Cretarhabdus crenulatus Zone. Cretarhabdus crenulatus 
TABLE 4 - Continued

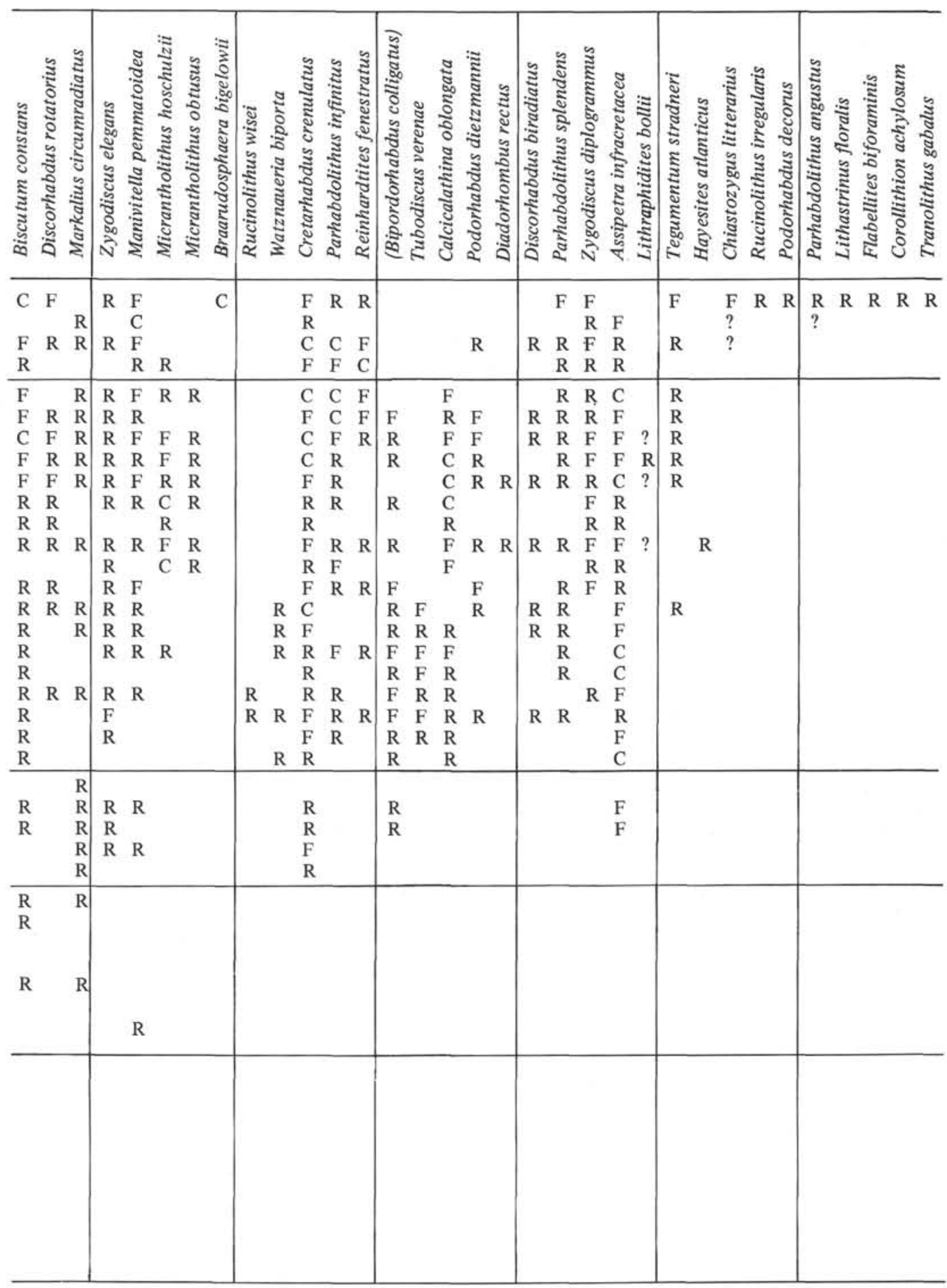

and Bipodorhabdus colligatus first occur in this zone. In contrast to the above, the preservation of the nannofossils in the thin claystone partings between thick limestone is generally poor in the Cretarhabdus crenulatus Zone and the underlying Nannoconus colomii Zone (Cores 391C-33 to -44).

Samples from Cores 391 C- 38 to -44 are placed in the upper Tithonian to lower Berriasian Nannoconus colomii Zone. Besides the index species, many characteristic Cretaceous species first occur in this zone such as Cretarhabdus conicus, Manivitella pemmatoidea, Lithraphidites carniolensis, Markalius circumradiatus, Parhabdolithus asper, and Zygodiscus elegans. Polycostella beckmannii has its last occurrence in the Nannoconus colomii Zone. All of these events are recognized in the Cores $391 \mathrm{C}-38$ to -44 interval.

Samples from Cores $391 \mathrm{C}-45$ to -54 are assigned to the lower Tithonian or upper Kimmeridgian Parhabdolithus embergeri Zone, as defined by the first occurrence of the index species below the first 
occurrence of nannoconids. Also Conusphaera mexicana and Polycostella beckmannii are reported to first occur in the Parhabdolithus embergeri Zone. Alternatively, this same interval (Cores 391C-45 to -54) can be referred to the Conusphaera mexicana Zone (Thierstein, 1975). Other characteristic species recorded from Kimmeridgian sediments (Barnard and Hay, 1974) which occur in this zone include Vekshinella quadriarculla, Podorhabdus cylindratus, Ethmorhabdus gallicus, Polypodorhabdus escaigii, and Zygodiscus sallilum (Table 4). The reddish claystone of Cores $391 \mathrm{C}-46$ to -54 contain moderately well preserved nannofossils in comparison to the overlying unit.

\section{TAXONOMY}

\section{Family EIFFELLITHACEAE Reinhardt, 1965}

Genus RHAGODISCUS Reinhardt, 1967

Type species: Discolithus asper Stradner, 1963

Rhagodiscus reniformis Perch-Nielsen, 1973

(Plate 3, Figures 2, 3)

Rhagodiscus reniformis Perch-Nielsen, 1973, p. 323, pl. 3, fig. 2,4,6; pl. 10 , fig. 45,46 .

Remarks: The kidney-like shape of this species is developed by an asymmetric thickening of the rim elements. The rim flares distally and the central area is filled with irregularly oriented elements, when viewed from the proximal side (Plate 3, Figure 3). This species most closely resembles Parhabdolithus splendens excluding the asymmetric development of the rim elements is mentioned above and a central spinal perforation in the latter. Rhagodiscus reniformis is thought to represent a late development in the "Parhabdolithus" asper-splendensangustus lineage; probably all these species should be placed in the genus Rhagodiscus.

Rhagodiscus reniformis should not be confused with Nephrolithus frequens (see Plate 3, Figure 1). The latter is also kidney-shaped, but the margin elements are equidimensional on all sides. The central area has a characteristic stellate arrangement of crystals (Plate 3, Figure 1b).

Occurrence: Upper Campanian-Maestrichtian, Cores 390A-11 to $-14 ; 390-2$.

\section{Genus ZYGODISCUS Bramlette and Sullivan, 1961} emend. Gartner, 1968

Type species: Zygodiscus adamas Bramlette and Sullivan, 1961

\section{Zygodiscus minimus Bukry, 1969}

(Plate 3, Figures 5, 6)

Zygodiscus minimus Bukry, 1969, p. 61, pl. 35, fig. 9-11.

Zygolithus tarboulensis Shafik and Stradner, 1971. Perch-Nielsen,

1973, pl. 10, fig. 31, 32 .

Remarks: This small species has a characteristic central structure comprised of a multi-element central bar supported by two inclined large crystals. Its appearance in the light microscope is illustrated by Perch-Nielsen (1973).

Occurrence: Upper Campanian-Maestrichtian, Cores 390A-11 to $-14,390-2$.

\section{Incertae Sedis}

Genus MICULA Vekshina, 1959

Type species: Micula decussata Vekshina, 1959

Micula mura (Martini, 1961) Bukry, 1973 (Plate 4, Figures 1-5)

Tetralithus murus Martini, 1961, p. 4, pl. 1, fig. 6; pl. 4, fig. 42. Bramlette and Martini, 1964, p. 320, pl. 6, fig. 18-21. Micula mura (Martini, 1961) Bukry, 1973, p. 679.
Remarks: As suggested by Bukry (1973), Micula mura resembles Micula decussata in basic design. Although Micula decussata is quite variable in upper Campanian-Maestrichtian samples, it consists essentially of eight elements compactly or loosely arranged into a cubical structure. The overlap of the crystals on opposite sides gives the characteristic cross pattern observed in polarized light. In some variants the elements elongate peripherally in a tangential fashion (Plate 4, Figure 8a-c). The top four elements are directed clockwise and upwards; the bottom set, counter-clockwise and downwards.

In forms transitional to Micula mura, one set of four elements is reduced, although geometrically they have the same arrangement of eight elements as Micula decussata (Plate 4, Figures 6, 7). In Micula mura, only a crown of four rudimentary elements remains while the other four elements are extended (Plate 4, Figures 1-5). Later in the development of the lineage, these elements formed longer, more curved rays. Only forms with relatively short extensions were observed in the samples from Site 390.

Occurrence: Late Maestrichtian, Micula mura Zone, Cores 390A11 to $-13 ; 390-2$.

\section{Genus HAYESITES Manivit, 1971}

Type species: Hayesites albiensis Manivit, 1971

Hayesites atlanticus (Wilcoxon, 1972) Thierstein, 1975 (Plate 5, Figures 9-11)

Discoaster? atlanticus Wilcoxon, 1972, p. 431, pl. 6, fig. 3, 4. Hayesites atlanticus (Wilcoxon, 1972) Thierstein, 1975, p. 85. Hayesites bulbus Thierstein in Roth and Thierstein, 1972, p. 438, pl. 2 , fig. $20-23$.

Remarks: This species is characterized by eight rays radiating from the center and by a raised rosette of crystals in the central area on the "distal" side (Plate 5, Figure 9). In a very few specimens a central process is built up of elongate crystal units parallel with the axis of the spine (Plate 5, Figure 10). It is possible that the asterolithlike structure and its raised knob are attached proximally to the distal end of a tapering central process. In this case, the concave side is oriented distally (Plate 5, Figure 11).

Occurrence: Barremian, Sample 44-392A-4, CC.

\section{SPECIES CONSIDERED}

A complete list of species referred to in this report would be rather long. For the Tertiary species, see Roth and Thierstein (1972), Roth (1973), and Martini (1976). For Mesozoic species, see Thierstein $(173,1976)$ and Barnard and Hay (1974). The following list gives alphabetically only those species figured, but not discussed in the taxonomy section, and other citations not found in the above references. Some remarks are added if clarification is necessary.

Figured specimens are deposited in the $\mathrm{CH}$-collection series of the Department of Stratigraphy and Paleontology. University of Utrecht. In the plate explanations, the $x-y$ locations listed after the Utrecht slide number refer to squares in a 200-mesh grid. Each figured specimen can be relocated in the light microscope by counting from the central V-marking (see Hansen et al., 1973).

\section{Cenozoic}

Amaurolithus tricorniculatus (Gartner, 1967) Gartner and Bukry, 1975

Biscutum? dimorphosum Perch-Nielsen, 1969. Plate 1, Figures 1, 2.

Braarudosphaera discula Bramlette and Riedel, 1954. Forms from the lower Paleocene listed as this species are composed of thick stacks of crystals reminiscent of Micrantholithus procerus Bukry and Bramlette, 1969. However, the cross-sections of fragments are similar to $B$. discula.

Campylosphaera dela (Bramlette and Sullivan, 1961) Hay and Mohler, 1967. Plate 1, Figure 3.

Chiasmolithus consuetus (Bramlette and Sullivan, 1961) Hay and Mohler, 1967. Plate 1, Figure 3

Chiasmolithus grandis (Bramlette and Riedel, 1954) Gartner, 1970. Plate 2, Figure 2 
Coccolithus cavus Hay and Mohler, 1967. Plate 1, Figure 5 small Coccolithus species. Plate 1, Figures 7, 8. These figures are similar to Ericsonia? martinii in Perch-Nielsen, 1969, pl. 4, fig. 14; NOT pl. 4, fig. 13.

Cruciplacolithus tenuis (Stradner, 1961) Hay and Mohler in Hay et al., 1967. Plate 1, Figure 6

Discoaster diastypus Bramlette and Sullivan, 1961. Plate 2, Figure 4

Discoaster mohleri Bukry and Percival, 1971. Plate 2, Figures 5, 6

Ellipsolithus distichus (Bramlette and Sullivan, 1961) Sullivan, 1964. Plate 2, Figure 8

Ericsonia subpertusa Hay and Mohler, 1967. Plate 1, Figure 4. This species probably should be placed in the genus Coccolithus (see Bukry, 1973, p. 676).

Fasciculithus tympaniformis Hay and Mohler in Hay et al., 1967. Plate 2, Figure 9

Markalius inversus (Deflandre in Deflandre and Fert, 1954) Bramlette and Martini, 1964. Plate 1, Figures 9, 10

Nannotetrina alata (Martini in Martini and Stradner, 1960) Haq and Lohmann, 1976

Sphenolithus furcatolithoides Locker, 1967. Plate 2, Figure 3

Toweius craticulus Hay and Mohler, 1967. Plate 2, Figure 7

Toweius petalosus Ellis and Lohman, 1973. This species should not be confused with small Thoracosphaera sp. of the lower Paleocene. Toweius petalosus and Biscutum dimorphosum are successional in their occurrence and may be related.

\section{Mesozoic}

Chiastozygus amphipons (Bramlette and Martini, 1964) Gartner, 1968. Plate 3, Figure 4

Cylindralithus serratus Bramlette and Martini, 1964. Plate 3, Figure 7

Eiffellithus eximius (Stover, 1966) Perch-Nielsen, 1968. Plate 5, Figure 7

Kamptnerius magnificus Deflandre, 1959. Plate 5, Figure 8

Lithraphidites quadratus Bramlette and Martini, 1964. Plate 3, Figure 10

Micula decussata Vekshina, 1959. Plate 4, Figure 8. Also forms as Micula decussata concava (Stradner in Martini and Stradner, 1960) Bukry, 1969 are present.

Nephrolithus frequens Gorka, 1957. Plate 3, Figure 1

Tetralithus aculeus (Stradner, 1961) Gartner, 1968. Plate 5, Figure 5, 6

Tetralithus gothicus Deflandre, 1959. Plate 5, Figures 3, 4

Tetralithus trifidus (Stradner in Stradner and Papp, 1961) Bukry, 1973. Plate 5, Figures 1, 2

Vagalapilla aachena Bukry, 1969. Plate 3, Figures 8, 9

Vekshinella crux (Deflandre and Fert, 1954) Shafik and Stradner, 1971

Zygodiscus sallilum (Noël, 1965) Wilcoxon, 1972.

\section{ACKNOWLEDGMENTS}

The author thanks Ben Prins, Shell, the Hague for valuable information on nannofossil taxonomy. The scanning electron micrographs were taken at the "Center for Submicroscopic Research" of the University of Amsterdam; I am grateful to C. Bakker for his assistance. I thank my wife, Margaret, for all her technical and moral support.

\section{REFERENCES}

Barnard, T. and Hay, W.W., 1974. On Jurassic coccoliths: a tentative zonation of southern England and north France: Eclog. Geol. Helv., v. 67, p. 563-585.

Berggren, , W.A., 1972. A Cenozoic time-some implications for regional geology and paleogeography: Lethaia, v. 5, p. $195-215$.

Bramlette, M.N. and Martini, E., 1964. The great change in calcareous nannoplankton fossils between the Maestrichtian and Danian: Micropaleontology, v. 10, p. 291-322.

Bramlette, M.N. and Riedel, W.R., 1954. Stratigraphic value of discoasters and some other microfossils related to Recent coccolithophores: Jr.. Paleontol., v. 28, p. 385403.
Bramlette, M.N. and Sullivan, F.R., 1961. Coccolithophorids and related nannoplankton of the early Tertiary in California: Micropaleontology, v. 7, p. 129-188.

Bukry, D., 1969. Upper Cretaceous coccoliths from Texas and Europe: Univ. Kansas Paleont. Contrib., Art. 51 (Protista 2), p. 1-79.

1973. Coccolith stratigraphy, eastern equatorial Pacific, Leg 16 Deep Sea Drilling Project. In van Andel, T.H., Heath, G.R., et al., Initial Reports of the Deep Sea Drilling Project, Volume 16: Washington (U.S. Government Printing Office), p. 653-711.

Bukry, D. and Bramlette, M.N., 1969. Some new and stratigraphically useful calcareous nannofossils of the Cenozoic: Tulane Stud. Geol., v. 7, p. 131-142.

Bukry, D. and Percival, S.J., Jr., 1971. New Tertiary calcareous nannofossils: Tulane Stud. Geol., v. 8, p. 123146.

Deflandre, G., 1959. Sur les nannofossiles calcaires et leur systématíque: Rev. Micropaléontol., v. 2, p. 127-152.

Deflandre, G. and Fert, C., 1954. Observations sur les Coccolithophoridés actuels et fossiles au microscope ordinaire et électronique: Ann. Paléont., v. 40, p. 115-176.

Ellis, H.C. and Lohman, W.H., 1973. Toweius petalosus, a Paleocene calcareous nannofossil from Alabama: Tulane Stud. Geol., v. 10, p. 107-110.

Gartner, S., Jr., 1967. Calcareous nannofossils from Neogene of Trinidad, Jamaica, and Gulf of Mexico: Univ. Kansas Paleont. Contrib., Paper 29, p. 1-7.

1968. Coccoliths and related calcareous nannofossils from Upper Cretaceous deposits of Texas and Arkansas: Univ. Kansas Paleont. Contrib. (Protista), p. 1-56.

1970. Phylogenetic lineages in the lower Tertiary coccolith genus Chiasmolithus: Proc. North American Paleont. Convention, pt. G, p. 930-957.

1971. Calcareous nannofossils from the JOIDES Blake Plateau cores, and revision of Paleogene nannofossil zonation: Tulane Stud. Geol., v. 8, p. 101-121.

Gartner, S. and Bukry, D., 1975. Morphology and phylogeny of the coccolithophycean Family Ceratolithaceae: Jr.. Res., U.S. Geol. Surv., v. 3, p. 451-465.

Gorka, H., 1957. Les Coccolithophoridés du Maestrichtian supérieur de Pologne: Acta Paleont. Polonica, v. 2, p. 235284.

Hansen, H.J., Schmidt, R.R., and Mikkelsen, N., 1975. Convertible techniques for the study of the same nannoplankton specimen: Proc. Kon. Ned. Akad. Wetensch., ser. B, v. 78, p. 225-230.

Haq, B. and Lohmann, G.P., 1976. Early Cenozoic calcareous nannoplankton biogeography of the Atlantic Ocean: Marine Micropaleontol., v. 1, p. 119-194.

Hay, W.W. and Mohler, H.P., 1967. Calcareous nannoplankton from early Tertiary rocks at Pont Labau, France, and Paleocene-early Eocene correlations: $J r$. Paleontol., v. 41, p. 1505-1541.

Hay, W.W., Mohler, H.P., Roth, P.H., Schmidt, R.R., and Boudreaux, J.E., 1967. Calcareous nannoplankton zonation of the Cenozoic of the Gulf Coast and Caribbean-Antillean area, and transoceanic correlations: Gulf Coast Assoc. Geol. Soc. Trans., v. 17, p. 428-480.

Locker, S., 1967. Neue Coccolithophoren (Flagellata) aus dem Altertertiär Norddeutschlands: Geologie, v. 16, p. 361-365.

Manivit, H., 1971. Nannofossiles calcaires du Crétacé Francaise (Aptien-Maestrichtien). Essai de biozonation appuyée sur les stratotypes: Thèse Doctorate d'Etat, Fac. Sci. d'Orsay, p. 1-167. 
Martini, E., 1961. Nannoplankton aus dem Tertiär und der obersten Kreide von S.W. Frankreich: Senck. Leth., v. 42, p. 1-32.

— 1971. Standard Tertiary and Quaternary calcareous nannoplankton zonation: Second Plankt. Conf. Proc., Roma 1970, v. 2, p. 739-785.

- 1976. Cretaceous to Recent calcareous nannoplankton from the central Pacific Ocean (DSDP Leg 33). In Schlanger, S.O., Jackson, E.D., et al., Initial Reports of the Deep Sea Drilling Project, Volume 33: Washington (U.S. Government Printing Office), p. 383423 .

Martini, E. and Stradner, H., 1960. Nannotetraster, eine stratigraphische bedeutsame neue Discoasteridengattung: Erdoel-Zeitschr., v. 76, p. 266-270.

Noël, D., 1965. Sur les Coccolithes du Jurassique Européen et de Afrique du Nord. Essai de classificatíon des coccolithes fossiles: Centre Natl. Rech. Sci., Paris, p. 1-209.

Perch-Nielsen, K., 1968. Der Feinbau und die Klassifikation der Coccolithen aus dem Maastrichtian von Dänemark: Biol. Skr., K. Danske Vid. Selskab, v. 16, p. 1-96. 1969. Die Coccolithen einiger dänischer Maastrichtien- und Danienlokalitäten: Medd. Dansk Geol. Foren., v. 19, p. 51-69. 1973. Neue Coccolithen aus dem Maastrichtien von Dänemark, Madagaskar und Agypten: Medd. Dansk Geol. Foren., v. 22, p. 306-333.

Reinhardt, P., 1965. Neue Familien für fossile Kalkflagellaten (Coccolithophoriden, Coccolithineen): Monatsber. Deutsch. Akad. Wiss. Berlin, v. 7, p. 30-40. 1967. Fossile Coccolithen mit rhagoiden Zentralfeld (Fam. Ahmuellerellaceae, Subord. Coccolithineae): Neues Jb. Geol. Pal. Monatsh., p. 163178.

Roth, P.H., 1973. Calcareous nannofossils-Leg 17, Deep Sea Drilling Project. In Winterer, E.L., Ewing, J.I., et al., Initial Reports of the Deep Sea Drilling Project, Volume 17: Washington (U.S. Government Printing Office), p. 695795.

Roth, P.H. and Thierstein, H.R., 1972. Calcareous nannoplankton: Leg 14 of the Deep Sea Drilling Project. In Hayes, D.E., Pimm, A.C., et al., Initial Reports of the Deep Sea Drilling Project, Volume 14: Washington (U.S. Government Printing Office), p. 421-485.

Ryan, W.B.F., Cita, M.B., Rawson, M.D., Burckle, L.H., and Saito, T., 1974. A paleomagnetic assignment of Neogene stage boundaries and the development of isochronous datum planes between the Mediterranean, the Pacific and Indian Oceans in order to investigate the response of the world oceans to the Mediterranean "salinity crisis": Riv. Ital. Paleont. Strat., v. 80, p. 631688.

Shafik, S. and Stradner, H., 1971. Nannofossils from the Eastern Desert, Egypt with reference to Maastrichtian nannofossils from the USSR: Jb. Geol. Bundesanst. Wien, Sonderband 17, p. 69-104.

Stradner, H., 1961. Vorkommen von Nannofossilien in Mesozoikum und Alttertiär: Erdoel-Zeitschr. v. 77, p. $77-$ 89.

1963. New Contributions to Mesozoic stratigraphy by means of nannofossils: Sixth World Petrol. Congr. Proc. (Frankfurt a. M.), sec. 1, paper 4, p. 1-16.

Stradner, H. and Papp, A., 1961. Tertiäre Discoasteriden aus Osterreich und deren stratigraphische Bedeutung mit Hinweisen auf Mexico, Rumänien und Italien: Jahr. Geol. Bundesanst. Wien, Sonderband 7, p. 1-159.

Stover, L.E., 1966. Cretaceous coccoliths and associated nannofossils from France and the Netherlands: Micropaleontology, v. 12, p. 133-167.

Sullivan, F.R., 1964. Lower Tertiary nannoplankton from the California Coast Ranges. I. Paleocene: Univ. Calif. Publ. Geol. Sci., v. 44, p. 163-228.

Thierstein, H.R., 1971. Tentative Lower Cretaceous calcareous nannoplankton zonation: Eclog. Geol. Helv., v. 64, p. $459-488$

1973. Lower Cretaceous calcareous nannoplankton biostratigraphy: Abh. Geol. Bundesanst. Wien, Band 29, p. 152.

1975. Calcareous nannoplankton biostratigraphy at the Jurassic-Cretaceous boundary: In Colloque sur la limite Jurassique-Crétacé, Lyon et Neuchâtel 1973: Mém. Bur. Recherches Géol. Min., v. 86, p. 85-94.

1976. Mesozoic calcareous nannoplankton biostratigraphy of marine sediments: Marine Micropaleontol., v. 1, p. 325-362.

van Hinte, J.E., 1976a. A Jurassic time scale: Am. Assoc. Petrol. Geol. Bull., v. 60, p. 489-497.

, 1976b. A Cretaceous time scale: Am. Assoc. Petrol. Geol. Bull., v. 60, p. 498-516.

Vekshina, V.N., 1959. Coccolithophoridae of the Maastrichtian deposits of west Siberian lowland: Trudy Sibir. Nauseh. Issled. Inst. Geol. Geofiz. i Min. Syr'ya, v. 2, p. 56-81.

Wilcoxon, J.A., 1972. Upper Jurassic-Lower Cretaceous calcareous nannoplankton from the western North Atlantic Basin. In Hollister, C. D., Ewing, J.I., et al., Initial Reports of the Deep Sea Drilling Project, Volume 11: Washington (U.S. Government Printing Office), p. $427-$ 457. 



\section{PLATE 1}

Scanning Electronic Micrographs of Lower Paleocene Microfossils

Figures 1,2 Biscutum dimorphosum Perch-Nielsen, 1969.

1. Coccosphere, $5000 \times(\mathrm{CH} \mathrm{3682:}+1,-4)$.

2. Collapsed coccosphere, $10,000 \times(\mathrm{CH} 3682$ : $+4,-2)$.

Sample 44-390A-10, CC.

Figure 3 Chiasmolithus consuetus (Bramlette and Sullivan, 1961) Hay and Mohler, 1967. Proximal view, 5000×, (CH 3683: -5, -5).

Sample 44-390A-8, CC.

Figure 4 Ericsonia subpertusa Hay and Mohler, 1967. Distal view, 5000×, $(\mathrm{CH} 3682:-6,-4)$.

Sample 44-390A-10, CC.

Figure 5 Coccolithus cavus (Hay and Mohler, 1967) PerchNielsen, 1969. Distal view, 5000×, (CH 3682: -1, $+1)$.

Sample 44-390A-10, CC.

Figure 6 Cruciplacolithus tenuis (Stradner, 1961) Hay and Mohler, 1967. Proximal view, 5000×, (CH 3682: $-6,-5)$.

Sample 44-390A-10, CC.

Figures 7,8 Small Coccolithus sp.

7a. Distal view.

7b. Oblique distal view, tilted $45^{\circ}, 10,000 \times$. $(\mathrm{CH}$ $3684:+1,-2)$.

8. Distal view, $10,000 \times,(\mathrm{CH} 3684:-3,+4)$. Sample 44-390A-11-5, $110 \mathrm{~cm}$.

Figures 9,10 Markalius inversus (Deflandre, 1954) Bramlette and Martini, 1964.

9. Distal view, 5000×, $(\mathrm{CH} \mathrm{3682:}+1,-2)$.

Sample 44-390A-11-5, $110 \mathrm{~cm}$.

10a. Proximal view.

10b. Oblique proximal view, tilted $30^{\circ},(\mathrm{CH} 3685$ : $+1,+2)$.

Sample 44-390A11-5, $145 \mathrm{~cm}$. 
PLATE 1
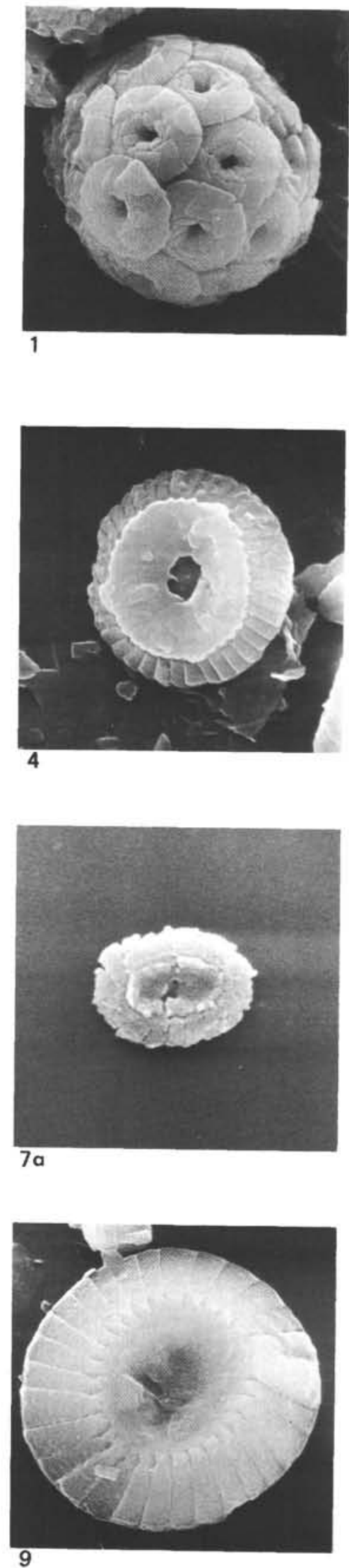
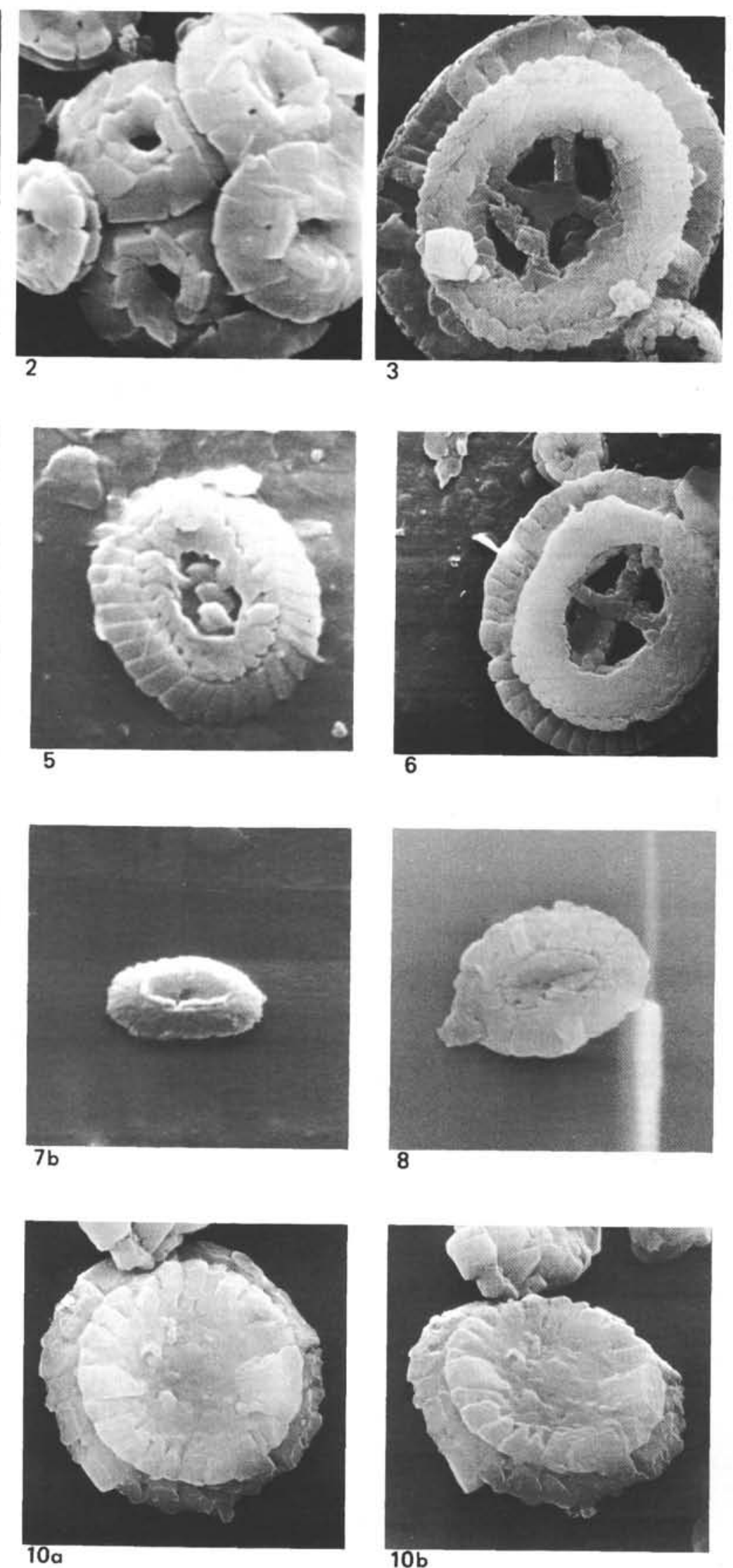
PLATE 2

Scanning Electron Micrographs of Upper Paleocene-Middle Eocene Nannofossils

Figure 1 Campylosphaera dela (Bramlette and Sullivan, 1961) Hay and Mohler, 1967. Proximal view, 5000×, (CH 3686: +5, +1).

Sample 44-390A-7, CC, Lower Eocene.

Figure 2 Chiasmolithus grandis (Bramlette and Riedel, 1954) Gartner, 1970. Proximal view, $2500 \times,(\mathrm{CH}$ 3687: $+5,-6)$.

Sample 44-390A-3, CC, middle Eocene.

Figure 3 Sphenolithus furcatolithoides Locker, 1967. Side view, 5000×, (CH 3687: +1, +7).

Sample 44-390A-3, CC, middle Eocene.

Figure 4 Discoaster diastypus Bramlette and Sullivan, 1961. 2500×, (CH 3686: -3, -2).

Sample 44-390A-7, CC, lower Eocene.

Figures 5,6 Discoaster mohleri Bukry and Percival, 1971.

5. $5000 \times,(\mathrm{CH} 3683:-1,+5)$.

6. 5000×, $(\mathrm{CH} \mathrm{3683:} \mathrm{+2,-4).}$

Sample 44-390A-8, CC, upper Paleocene.

Figure $7 \quad$ Toweius craticulus Hay and Mohler, 1967.

7a. Distal view.

7b. Oblique distal view, tilted $45^{\circ}, 5000 \times,(\mathrm{CH}$ 3683: $-2,-6)$.

Sample 44-390A-8, CC, upper Paleocene.

Figure 8 Ellipsolithus distichus (Bramlette and Sullivan, 1961) Sullivan, 1964.

8a. Distal view.

8b. Oblique distal view, tilted $45^{\circ}, 5000 \times,(\mathrm{CH}$ 3683: $-1,-3)$.

Sample 44-390A-8, CC, upper Paleocene.

Figure 9 Fasciculithus tympaniformis Hay and Mohler, 1967.

9a. Side view.

9b. Oblique side view, tilted $45^{\circ}, 5000 \times(\mathrm{CH}$ 3683: $-1,-3)$.

Sample 44-390A-8, CC, upper Paleocene. 
PLATE 2
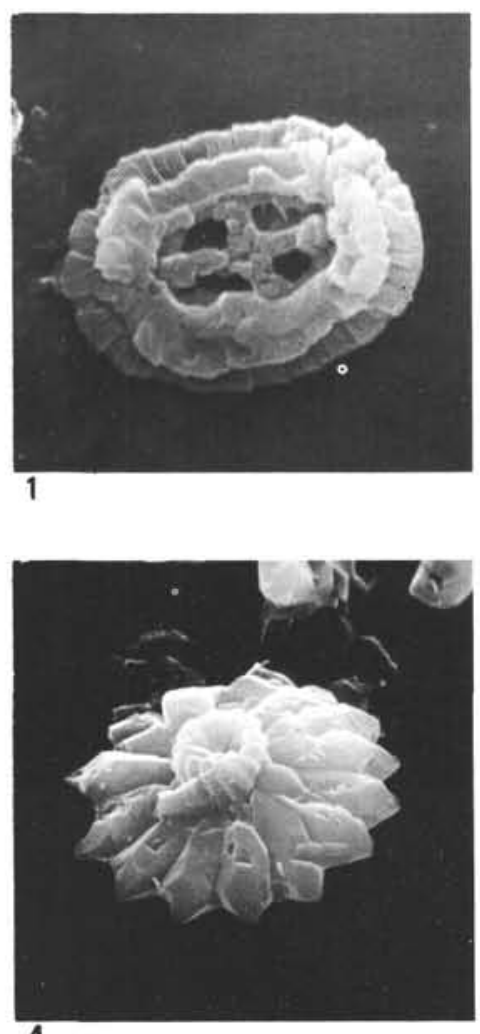

4
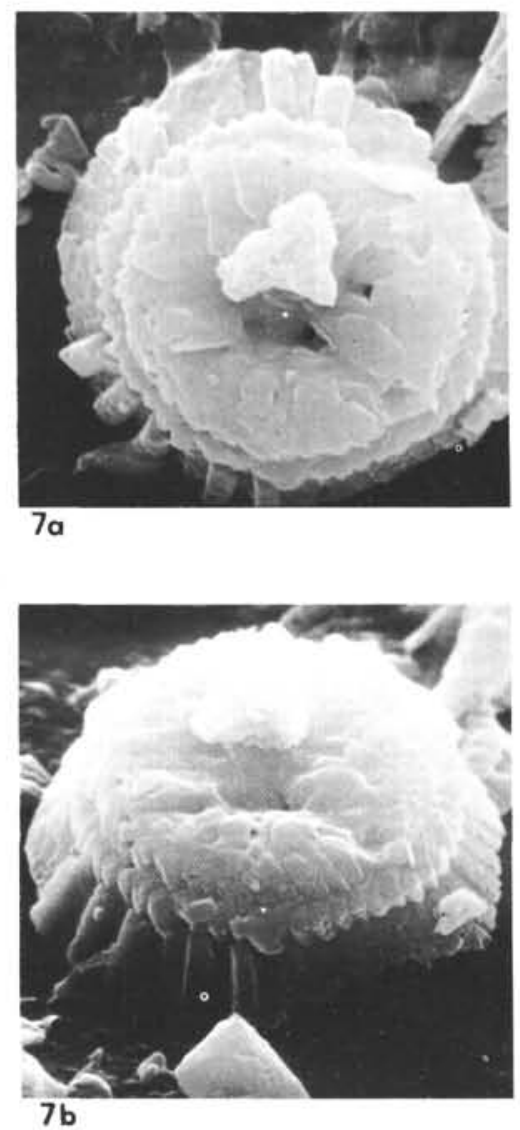
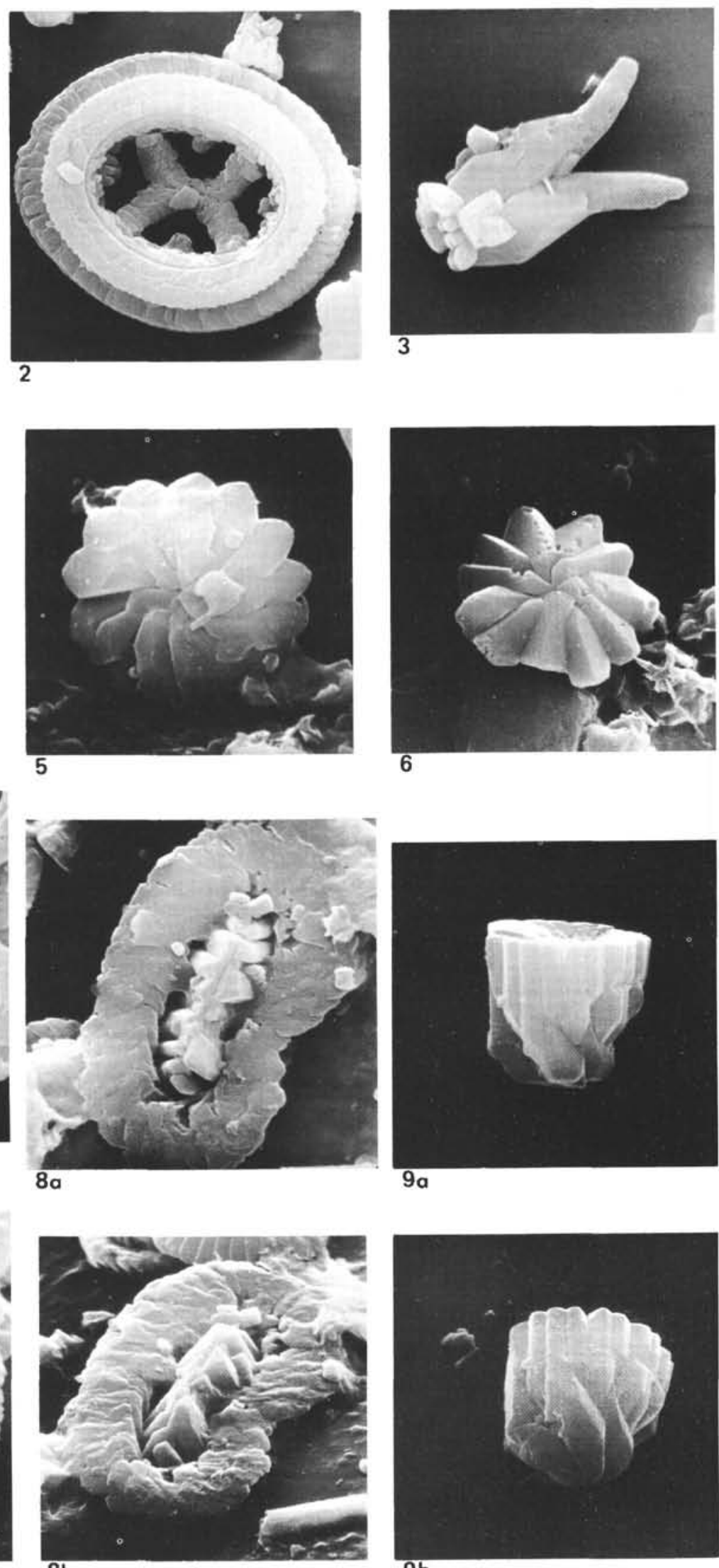

$8 b$

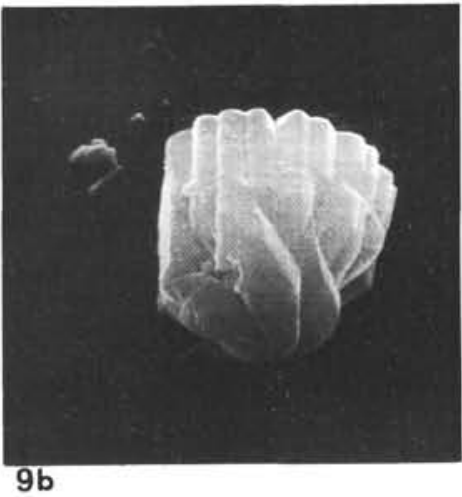


PLATE 3

Scanning Electron Micrographs of Upper Cretaceous Nannofossils

Figure $1 \quad$ Nephrolithus frequens Gorka, 1957.

1a. Distal view, $5000 \times$.

1b. Enlargement, 10,000X.

1c. Oblique distal view, tilted $45^{\circ}, 5000 \times,(\mathrm{CH}$ 3688: $+6,-1)$.

Sample 44-390A-11, CC, upper Maestrichtian.

Figures 2, 3 Rhagodiscus reniformis Perch-Nielsen, 1973.

2. Distal view, $5000 \times(\mathrm{CH} 3689:-2,-4)$.

Sample 44-390A-14-5, $72 \mathrm{~cm}$, late Campanian.

3. Proximal view, $5000 \times,(\mathrm{CH} 3690:-5,+1)$.

Sample 44-390-2, CC, upper Maestrichtian.

Figure $4 \quad$ Chiastozygus amphipons (Bramlette and Martini, 1964) Gartner, 1968. Distal view, 5000X, $(\mathrm{CH}$ 3688: $-6,+1)$.

Sample 44-390A-11, CC, upper Maestrichtian.

Figures 5,6 Zygodiscus minimus Bukry, 1969.

5. Distal view, $10,000 \times,(\mathrm{CH} 3688:-1,-7)$.

6. Proximal view, $10,000 \times,(\mathrm{CH} 3688:+1,+6)$.

Sample 44-390A-11, CC, upper Maestrichtian.

Figure 7 Cylindralithus serratus Bramlette and Martini, 1964. Oblique side view, $5000 \times,(\mathrm{CH} 3688:+6$, $-1)$.

Sample 44-390A-11, CC, upper Maestrichtian.

Figures 8,9 Vagalapilla aachena Bukry, 1969.

8. Distal view, 10,000×, $(\mathrm{CH} 3688:+2,-6)$.

9. Proximal view, $10,000 \times,(\mathrm{CH} 3688:-4,-4)$.

Sample 44-390A-11, CC, upper Maestrichtian.

Figure 10 Lithraphidites quadratus Bramlette and Martini, 1964. Side view, 5000×, (CH 3690: -2, -4).

Sample 44-390-2, CC, upper Maestrichtian. 
PLATE 3
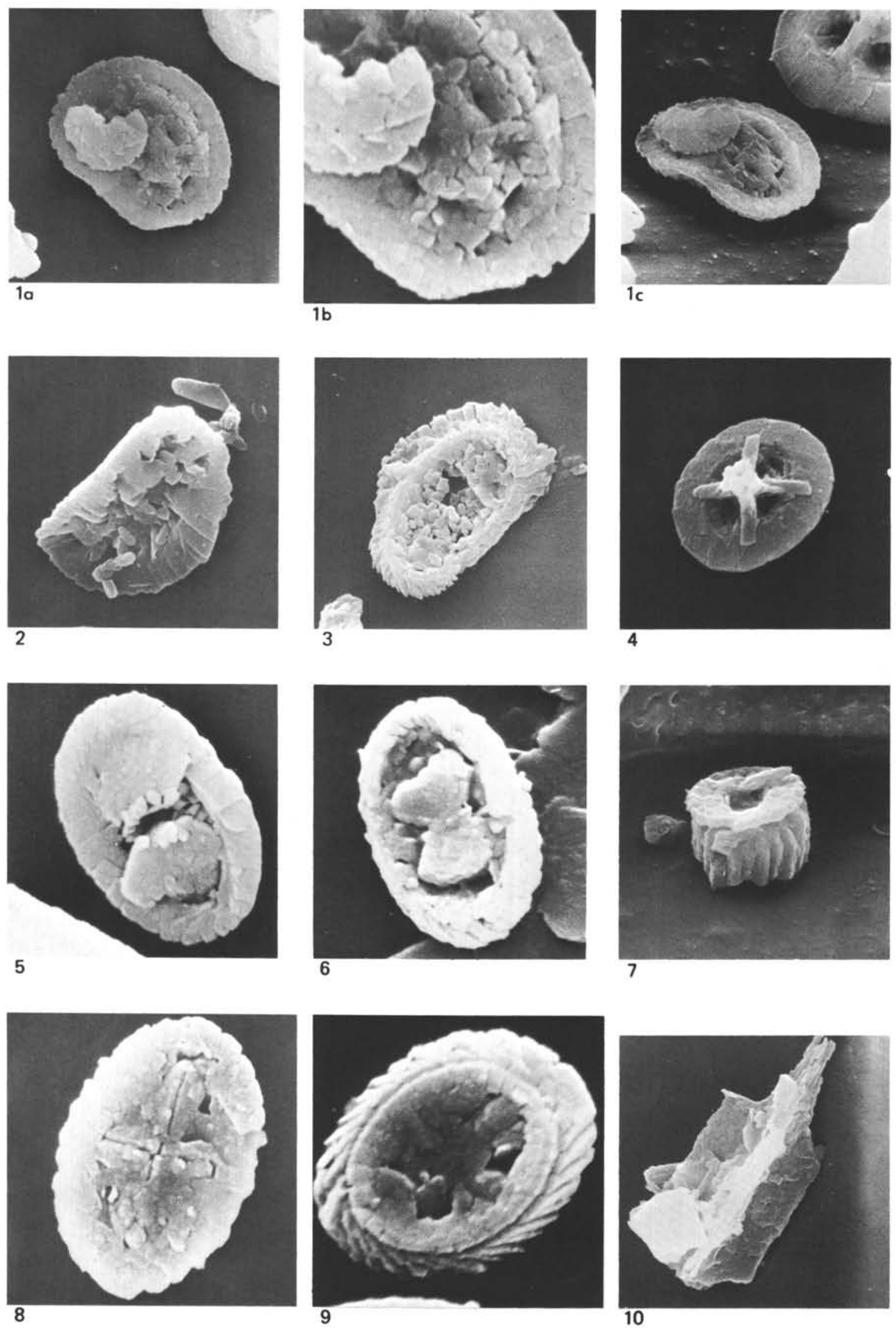


\section{PLATE 4}

Scanning Electron Micrographs of Nannofossils of the Micula decussata-mura Lineage, Upper Maestrichtian

Figures 1-5 Micula mura (Martini, 1961) Bukry, 1973.

1. Broken specimen, side view, 5000×, $(\mathrm{CH}$ 3688: $+6,-1)$.

Sample 44-390A-11, CC

2. Oblique concave view, $5000 \times,(\mathrm{CH} 3691:+1$, $-6)$.

Sample 44-390A-12-1, $73 \mathrm{~cm}$.

3. Side view, $5000 \times,(\mathrm{CH} \mathrm{3688:}+7,+1)$.

Sample 44-390A-11, CC.

4. Convex view, 10,000×, $(\mathrm{CH} 3691:-4,+1)$.

Sample 44-390A-12-1, $73 \mathrm{~cm}$.

5. Oblique convex view, $5000 \times,(\mathrm{CH} 3688:+3$, 1).

Sample 44-390A-11, CC.

Figures 6,7 Micula of $M$. decussata Vekshina, 1959.

$6 \mathrm{a}$. Top set of 4 elements reduced.

6b.As above, tilted $45^{\circ}, 5000 \times,(\mathrm{CH}$ 3692: -1 , +2 ).

7a. Small specimen with tangential arrangement of elements.

7b.Reduced set of 4 elements underneath, tilted $30^{\circ}, 10,000 \times,(\mathrm{CH} \mathrm{3688:}+7,+1)$.

Sample 44-390A-11, CC.

Figure $8 \quad$ Micula decussata Vekshina, 1959.

8 a. All 8 elements of equal size.

8 b. As above, tilted $30^{\circ}$.

8c. As above, tilted $65^{\circ}, 5000 \times,(\mathrm{CH} 3688$ : +6 , 1).

Sample 44-390A-11, CC. 
PLATE 4
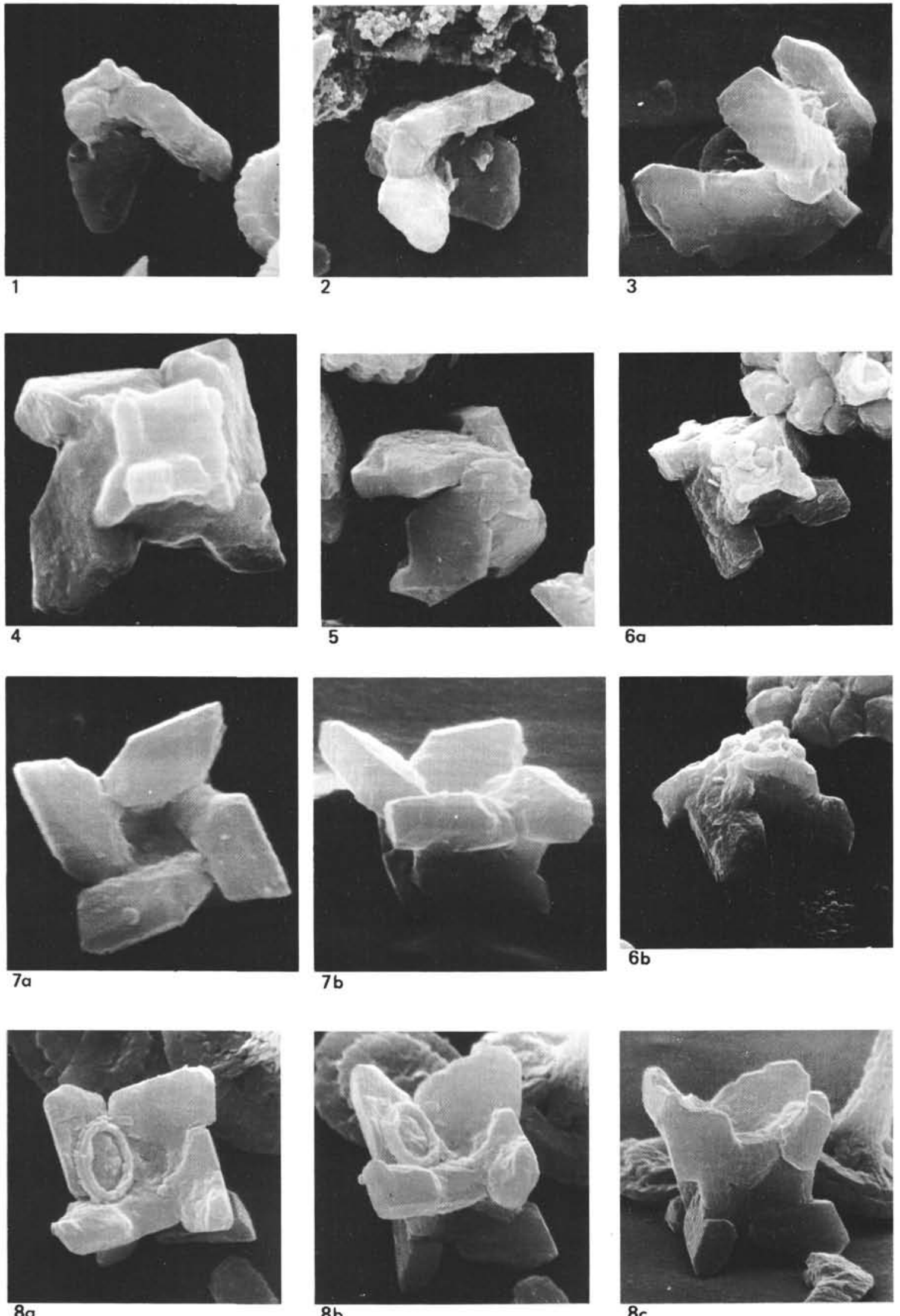


\section{PLATE 5}

Scanning Electron Micrographs of Cretaceous Nannofossils

Figures 1, 2 Tetralithus trifidus (Stradner, 1961) Bukry, 1973.

1. Short-rayed form, $5000 \times,(\mathrm{CH} 3689:+6,+1)$.

2. Long-rayed form, $2500 \times,(\mathrm{CH} 3693:+1,-6)$.

Sample 44-390A-14-5, $72 \mathrm{~cm}$, upper Campanian.

Figures 3, 4 Tetralithus gothicus Deflandre, 1959.

3. Short-rayed form, $5000 \times,(\mathrm{CH} 3693:-2,+7)$.

4. Long-rayed form, $2500 \times$, ( $\mathrm{CH} 3693:-2,+7)$.

Sample 44-390A-14-5, $72 \mathrm{~cm}$, upper Campanian.

Figures 5, 6 Tetralithus aculeus (Stradner, 1961) Gartner, 1968.

5. Short terminal elongation, $5000 \times,(\mathrm{CH} 3689$ : $2,+6)$.

6. Long terminal elongation, $5000 \times,(\mathrm{CH} 3689$ : $5,-3)$.

Sample 44-390A-14-5, $72 \mathrm{~cm}$, upper Campanian.

Figure 7 Eiffellithus eximius (Stover, 1966) Perch-Nielsen, 1968.

7a.Distal view.

7b.Oblique distal view, tilted $15^{\circ}, 5000 \times,(\mathrm{CH}$ 3693: $-4,-1)$.

Sample 44-390A-14-5, $72 \mathrm{~cm}$, upper Campanian.

Figure $8 \quad$ Kamptnerius magnificus Deflandre, 1959. Distal view, 2500×, (CH 3693: +1, -2).

Sample 44-390A-14-5, $72 \mathrm{~cm}$, upper Campanian.

Figures 9-11 Hayesites atlanticus (Wilcoxon, 1972) Thierstein, 1975.

9. Distal view, $5000 \times,(\mathrm{CH} 3694:+3,+2)$.

10. Side view, 5000×, (CH 3694: +7, -3).

11. Proximal view, $5000 \times$, $(\mathrm{CH} 3695:-4,-5)$.

Sample 44-392A-4, CC, Barremian. 
PLATE 5
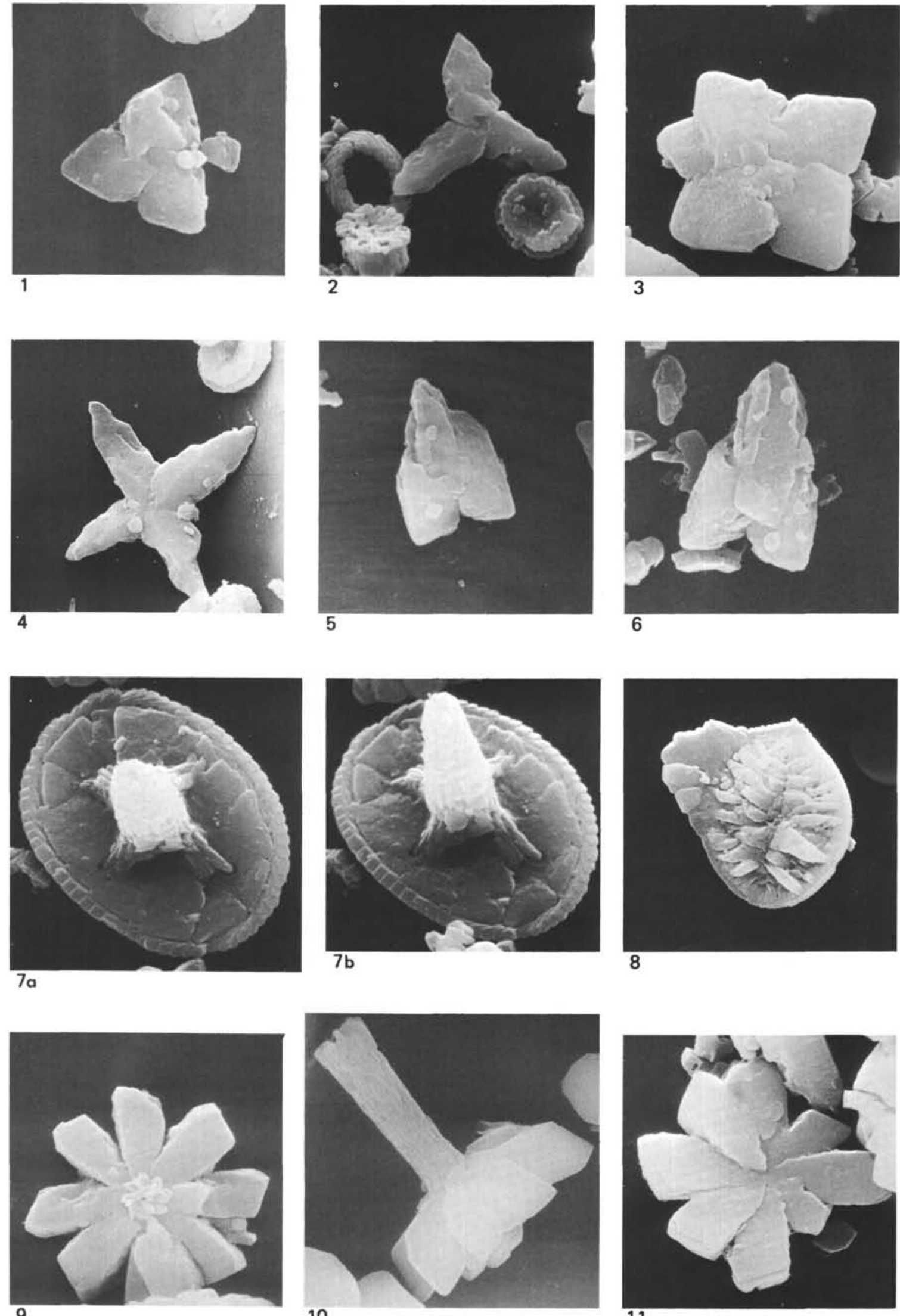

11 